\title{
PRINCÍPIOS DO DIREITO ANIMAL BRASILEIRO
}

\author{
PRINCIPLES OF THE BRAZILIAN ANIMAL LAW
}

Recebido: 07.06.2019

Aprovado: 25.03 .2020

\author{
Vicente de Paula Ataide Junior \\ Pós-doutor em Direito Animal UFBA. Doutor pela \\ UFPR. Professor UFPR. Juiz Federal titular no \\ Paraná. \\ EMAIL: vicente.junior@ufpr.br \\ LATTES: \\ wwws.cnpq.br/cvlattesweb/PKG_MENU.menu?f_ \\ cod=D51B4D1287369F6BD0B5BAA2A7BD4125\# \\ ORCID:http:/ / orcid.org/0000-0003-4995-9928
}

RESUMO: É significativa a carência de estudos doutrinários sobre a dogmática e a principiologia do Direito Animal. Nesse contexto, o artigo tem o objetivo de lançar uma proposta de princípios jurídicos, exclusivos e não-exclusivos (compartilhados com outros ramos jurídicos), para o Direito Animal, extraídos do ordenamento jurídico brasileiro, sobretudo do estrato constitucional, com o auxílio da teoria dos princípios de Humberto Ávila. Para tanto, enfrenta duas questões epistemológicas preliminares: a fixação da denominação e do conceito da disciplina jurídica estudada, que permitam bem identificar o objeto desse novo campo da enciclopédia jurídica. Direito Animal é a denominação proposta para fins de uniformização terminológica. O conceito para a disciplina leva em consideração o reconhecimento da sua autonomia em relação ao Direito Ambiental. Nesse particular, procede-se à desconstrução analítica do conceito proposto, para permitir a análise de seus elementos essenciais. Conforme se propõe, os princípios exclusivos ou típicos do Direito Animal são os seguintes: 1) princípio da dignidade animal; 2) princípio da universalidade; 3) princípio da primazia da liberdade natural e 4) princípio da educação animalista. Por sua vez, os princípios não-exclusivos ou compartilhados do Direito Animal têm uma listagem mais aberta, podendo ser indicados, ao menos, os seguintes: 1) princípio da precaução; 2) princípio da democracia participativa; 3) princípio do acesso à justiça e 4) princípio da proibição do retrocesso. Como se pode intuir, o estabelecimento teórico da denominação, do conceito e da principiologia própria do Direito Animal, ainda não discutidos pela comunidade científica, é essencial para a sua elaboração dogmática e para seu reconhecimento autônomo dentre as demais disciplinas jurídicas.

PALAVRAS-CHAVE: Direito animal. Conceito de direito animal. Princípios do direito animal. Princípio da dignidade animal. Direitos fundamentais animais.

\begin{abstract}
There is a significant lack of doctrinal studies on dogmatics and the legal principles of Animal Law. In this context, the article aims to launch a proposal of legal principles, exclusive and non-exclusive (shared with other legal branches), for Animal Law, taken from the brazilian legal system, above all from the constitutional stratum, with the help of the theory of the legal principles of Humberto Ávila. To this end, it faces two preliminary epistemological questions: the fixation of the denomination and the concept of the studied legal discipline, which allow the identification of the object of this new field of legal encyclopedia. The methodology, therefore, is hypothetical-deductive. Animal Law is the proposed name for the purpose of uniform terminology. The concept for the discipline takes into account the recognition of its autonomy in relation to Environmental Law. In this regard, the analytical deconstruction of the proposed concept is proceeded to allow the analysis of its
\end{abstract}


essential elements. As proposed, the exclusive or typical principles of Animal Law are as follows: 1) principle of animal dignity; 2) principle of universality; 3) the principle of primacy of natural freedom; and 4) the principle of animalistic education. In turn, the non-exclusive or shared principles of Animal Law have a more open listing, at least the following can be indicated: 1) precautionary principle; 2) the principle of participatory democracy; 3) the principle of access to justice; and 4) the principle of non-regression. As can be seen, the theoretical establishment of the denomination, concept and principle of Animal Law, not yet discussed by the scientific community, is essential for its dogmatic elaboration and for its autonomous recognition among the other legal disciplines.

KEYWORDS: Animal law. Animal law concept. Principles of animal law. Principle of animal dignity. Fundamental animal rights.

SUMÁRIO: 1 Introdução 2 Denominação 3 O conceito de Direito Animal 4 Princípios do Direito Animal brasileiro 4.1 Princípio da dignidade animal 4.2 Princípio da universalidade 4.3 Princípio da primazia da liberdade natural 4.4 Princípio da educação animalista 5 Princípios compartilhados pelo Direito Animal com outros ramos jurídicos 5.1 Princípio da precaução 5.2 Princípio da democracia participativa 5.3 Princípio do acesso à justiça $\mathbf{5 . 4}$ Princípio da proibição do retrocesso 6 Conclusões propositivas 7 Referências

\section{Introdução}

Este ensaio apresenta notas propedêuticas sobre o Direito Animal, na perspectiva do ordenamento jurídico brasileiro, oferecendo uma proposta para o desenvolvimento de seus princípios jurídicos, a partir do referencial teórico de Humberto Ávila (2018).

A teoria dos princípios de Humberto Ávila é a que oferece, atualmente, as melhores respostas para os dilemas sobre a diferenciação e a aplicação de regras e princípios, superando as insuficiências das teorias tradicionais construídas a partir, sobretudo, das contribuições de Ronald Dworkin e Robert Alexy.

Mais do que uma teoria conceitual, as inovações oferecidas por Humberto Ávila possibilitam um enfrentamento efetivo do problema da relativização axiológica gerada pelas inadequadas distinções, as quais alçaram os princípios a um patamar de tábua de salvação de fundamentações decisórias arbitrárias e sem qualquer racionalidade argumentativa, sobretudo a partir do uso dos "princípios" da razoabilidade e da proporcionalidade. ${ }^{1}$

Evidentemente, dadas às limitações de um artigo, não será possível esmiuçar toda a teoria de Humberto Ávila sobre a aplicação dos princípios jurídicos, nem muito menos cotejá-la com as demais teorias. Neste trabalho, os conceitos e concepções dessa teoria serão utilizados como ferramentas para a elaboração de uma principiologia do Direito Animal. Na medida do possível, esclarecimentos adicionais serão fornecidos em notas de rodapé. O leitor, no entanto, terá facilidade para se acercar da teoria completa, e fazer seus juízos sobre ela, recorrendo à obra central do seu pensamento, indicada ao final.

Com esse propósito e com esse referencial, o trabalho começa por abordar dois temas epistemológicos preliminares, sem os quais não se pode passar à tarefa de investigar os respectivos princípios jurídicos: a denominação e o conceito da nova disciplina jurídica.

A importância de se fixar e uniformizar a denominação está ligada ao reconhecimento, à identificação e à localização do novo ramo jurídico, no amplo espectro das especializações historicamente desenvolvidas no Direito.

\footnotetext{
${ }^{1}$ Nesse sentido, é conhecida a crítica de Eros Grau ao afirmar, categoricamente, que "Os juízes despedaçam a segurança jurídica quando abusam do uso de 'princípios' e praticam - fazem-no cotidianamente! - os controles da proporcionalidade e da razoabilidade das leis." (GRAU, Eros. Por que tenho medo dos juízes: a interpretação/aplicação do direito e os princípios. 9. ed. São Paulo: Malheiros, 2018. p. 24). 
O conceito, por sua vez, é necessário para se delimitar o objeto da disciplina e, a partir dele, construir suas balizas e contornos teóricos, reforçando sua autonomia e sua dignidade científicas. Se o Direito Animal existe, é necessário que possa ser adequadamente identificado e reconhecido, sem o que não poderá frutificar para atuar mais eficazmente no mundo prático.

Nesse substrato é que serão identificados, no âmbito do direito positivo brasileiro, os princípios do Direito Animal, os quais, como modalidades normativas, são de aplicação obrigatória. O objetivo é "procurar dar um contorno ou um perfil semântico ao padrão a ser consolidado como princípio", ${ }^{2}$ dentro do Direito Animal. Ainda que não seja possível percorrer todo o caminho proposto por Humberto Ávila para a análise dos princípios, especialmente no que pertine à catalogação dos casos paradigmáticos que possam indicar a composição dos princípios propostos, ${ }^{3}$ acredita-se que este trabalho possa contribuir para os primeiros passos.

Trata-se, é preciso advertir, de uma proposta preliminar, sujeita às imperfeições de toda contribuição inédita, ainda não submetida às críticas da comunidade científica. É tarefa urgente, porque toda disciplina jurídica autônoma precisa ostentar seu catálogo próprio de princípios, não por capricho doutrinário, ou para correções de índole moral, mas por exigência da sua própria juridicidade.

Respostas mais consistentes são diariamente cobradas dos juristas animalistas, no sentido de se delinear instrumentos jurídicos consistentes, factíveis e operacionais para a realização dos direitos fundamentais animais.

É hora, portanto, de migrar da fundamentação exclusivamente filosófica dos direitos animais, em direção à sua consolidação dogmática, para que o Direito Animal frequente, com mais assiduidade e qualidade, os juízos e tribunais brasileiros, concretizando a tutela jurisdicional adequada e efetiva da dignidade animal.

Para fechar essa introdução, e revelar o espírito desta proposta, melhores são as palavras de Tércio Sampaio Ferraz Junior, para o qual "A dogmática prepara, pois, a decisão, cria para ela condições razoáveis, de tal modo que ela não apareça como puro arbítrio, mas decorra de argumentos plausíveis." ${ }^{4}$

\section{Denominação}

Antes de se catalogar princípios, é preciso saber de que parte do Direito se está tratando. ${ }^{5}$

\footnotetext{
${ }^{2}$ Ainda que refratário à ideia de se construir princípios a priori, antes do caso concreto, essa possibilidade de se estabelecer o "perfil semântico" dos princípios é admitida por Lenio Luiz Streck (STRECK, Lenio Luiz. Verdade e consenso: constituição, hermenêutica e teorias discursivas. 5. ed. São Paulo: Saraiva, 2014. p. 575).

${ }^{3}$ ÁVILA, Humberto Bergmann. Teoria dos princípios: da definição à aplicação dos princípios jurídicos. 18. ed. São Paulo: Malheiros, 2018. p. 116-122.

${ }^{4}$ FERRAZ JUNIOR, Tércio Sampaio. Introdução ao estudo do direito: técnica, decisão, dominação. 3. ed. São Paulo: Atlas, 2001. p. 92.

${ }^{5}$ Lenio Luiz Streck, na sua extensa crítica às teorias dissociativas tradicionais entre regras e princípios, também se opõe à construção de princípios em campos específicos do direito, como princípios do direito processual, do direito administrativo, do direito penal, etc., afirmando-os como destituídos de significado pragmático, especialmente para influir e para legitimar, democraticamente, as decisões judiciais (op. cit., p. 549). O Direito Animal, particularmente, tem padecido pela absoluta ausência de princípios que possam, adequada e racionalmente, orientar as decisões judiciais que digam respeito à tutela jurídica dos animais. Nenhum princípio do Direito Animal é citado em decisões judiciais. Não porque não existam, mas porque a doutrina ainda não os catalogou. Como resultado, a falta de coerência e de fundamentação adequada das decisões, nesse campo, são sentidas. Uma proposta de catalogação a priori de princípios tem por objetivo facilitar a aplicação do Direito Animal, pela antecipação do seu "perfil semântico", o qual, ao mesmo tempo, ampliará a percepção dos juízes para as especificidades do novo campo do direito positivo e reduzirá as chances de decisões desapegadas das novas concepções constitucionais, como em relação à senciência e à dignidade animais.
}

108 |Revista do Programa de Pós-Graduação em Direito da UFBA, e-issn 2358-4777, v. 30, n. 01, p. 106 -136, Jan-Jun 2020 
Essa tarefa preliminar consiste, basicamente, na individualização do objeto desse novo campo, por meio da fixação de sua denominação e da elaboração do seu perfil conceitual.

Todo novo campo do saber, com pretensões de autonomia e reconhecimento, precisa fixar e uniformizar sua denominação: trata-se de uma questão de identidade.

Justifica-se essa preocupação até por questões operacionais das práticas científicas: as buscas por artigos científicos, livros, dissertações e teses são otimizadas quando se tem um padrão de nomenclatura da disciplina. Sem esse padrão, corre-se o risco de perda ou de falta de acesso a trabalhos científicos importantes, por variações de denominação dentre as palavraschave.

Ainda não há consenso - por falta de uma discussão científica mais aprofundada - quanto à adequada denominação da nova disciplina jurídica, objeto deste ensaio.

Registra-se a disputa entre as denominações Direito Animal ${ }^{6}$ (como no inglês Animal Law) e Direito dos Animais ${ }^{7}$ (mais próxima de animal rights).

Nesse momento de confirmação científica, é necessário adotar uma terminologia que, ao mesmo tempo, expresse o objeto da nova ciência normativa e bem se adapte ao padrão das demais disciplinas jurídicas.

No campo jurídico em estudo, o animal não-humano, como indivíduo dotado de dignidade própria, é centro da juridicização: isso justifica as denominações em conflito.

Não se ignora, no entanto, as objeções filosóficas quanto à adoção da palavra animal para designar o campo jurídico, excluindo de seu âmbito os humanos, dado que, inequivocamente, os humanos são animais. Essa terminologia pode favorecer os discursos especistas, ${ }^{8}$ pelos quais se separam, arbitrariamente, animais humanos e animais não-humanos. ${ }^{9}$ No entanto, Direito Animal, como se verá, realmente se destina a disciplinar e a ordenar os direitos fundamentais dos animais não-humanos, não tratando de direitos fundamentais humanos, para os quais várias disciplinas jurídicas se repartem para deles tratar. ${ }^{10}$

Portanto, dado o objeto traçado para a disciplina - os direitos fundamentais de animais não-humanos -, quer parecer que a decisão sobre a melhor terminologia deve se dar mesmo entre Direito Animal e Direito dos Animais.

Nessa linha, parece mais adequado seguir o padrão de diferenciação adotado pelas denominações em língua inglesa: Animal Law (Direito Animal) como a disciplina jurídica ou o direito objetivo, e Animal Rights (Direitos Animais), como expressão adequada para referir aos respectivos direitos subjetivos.

Por outro lado, no Brasil, fala-se em Direito Ambiental (e não Direito dos Ambientes), Direito Penal (e não Direito das Penas), Direito Civil (e não Direito das Relações Civis), Direito Processual (e não Direito dos Processos), Direito Empresarial (e não Direito das Empresas), etc., o que aponta a adequação, para fins de uniformidade, da denominação Direito Animal - ao invés

\footnotetext{
${ }^{6}$ Direito Animal é a denominação preferida, dentre outros, por Heron José de Santana Gordilho, Anaiva Oberst Cordovil e Tagore Trajano de Almeida Silva.

${ }^{7}$ Essa denominação é adotada, por exemplo, no clássico livro de Daniel Braga Lourenço: Direito dos Animais: fundamentação e novas perspectivas. Também adotam a mesma denominação Diomar Ackel Filho, Laerte Fernando Levai, Fernanda Luiza Fontoura de Medeiros e Carla de Abreu Medeiros.

${ }^{8}$ A palavra especismo foi criada por Richard Ryder (originalmente, em inglês, speciesism) e difundida por Peter Singer, a partir dos anos 70 do século XX, para significar "o preconceito ou a atitude de alguém a favor dos interesses de membros da própria espécie e contra os de outras." (SINGER, Peter. Libertação animal. Salvador: Lugano, 2004. p. 8).

9 TRINDADE, Gabriel Garmendia da. Especismo, linguagem e a percepção humana dos demais animais. In: SCHEFFER, Gisele Kronhardt (coord.). Direito Animal e ciências criminais. Porto Alegre: Canal Ciências Criminais, 2018. p. 59-66.

10 Para outras denominações para essa área do saber, propostas pela filosofia, ver: DUNAYER, Joan. Animal equality: language and liberation. Derwood: Ryce Publishing, 2001.
}

109 |Revista do Programa de Pós-Graduação em Direito da UFBA, e-issn 2358-4777, v. 30, n. 01, p.106 - 136, Jan-Jun 2020 
de Direito dos Animais - pois se trata de expressão mais ajustada à padronização nominativa das especializações jurídicas hoje já bem consolidadas.

Com razão Tagore Trajano de Almeida Silva, quando diz

[...] importante unificar a terminologia da disciplina, adotando a nomenclatura 'Direito Animal', a fim de evitar interpretações sectárias que dividam a matéria e seu objeto de estudo. Esta elucidação impede a confusão de termos e explicações a criar inúmeras terminologias, tais como: 'direitos animais', 'direito dos animais', 'direitos dos animais', 'direitos dos não-humanos', 'direitos dos animais não-humanos', etc. para tratar do mesmo processo de evolução do Direito Animal. ${ }^{11}$

Mesmo sem consenso, a denominação Direito Animal já conta com adesões importantes.

Em 2006, por exemplo, foi fundada a mais importante revista jurídica latino-americana sobre o tema, a Revista Brasileira de Direito Animal (RBDA), ${ }^{12}$ indexada no estrato A1 da avaliação brasileira de periódicos científicos (QUALIS-CAPES, conforme última avaliação, do quadriênio 2013-2016), ${ }^{13}$ com a expressa adoção da denominação proposta.

$\mathrm{Na}$ Carta de Sergipe, os juristas e outros participantes do V Congresso Brasileiro e II Congresso Latino-Americano de Bioética e Direitos dos Animais, ocorrido em setembro de 2019, na Universidade Federal do Sergipe (UFS), adotaram, dentre outros, o seguinte enunciado: "Afirmar a necessidade de uniformização da denominação da disciplina jurídica como Direito Animal (em vez de Direito dos Animais), como condição necessária para a autonomia científica desse novo ramo do Direito." ${ }^{14}$

Consequentemente, propõe-se uma revisão terminológica para que os estudos científicos passem a se referir à disciplina em tela como Direito Animal, evitando-se o uso da denominação Direito dos Animais.

Por fim, anote-se que o adjetivo animalista pode ser usado para designar, não a disciplina jurídica em si, mas as manifestações que lhe são correlatas, como doutrina animalista ou jurista animalista, da mesma forma como se faz, por exemplo, no Direito Civil, em que a doutrina é civilista e os respectivos juristas são chamados de civilistas e, no Direito Penal, a doutrina é penalista e juristas são penalistas. ${ }^{15}$

\section{0 conceito de Direito Animal}

Da mesma forma com o que acontece com a denominação, não há como avançar cientificamente sem se fixar um conceito para o Direito Animal, elaborado a partir do próprio ordenamento jurídico, sobretudo do seu estrato constitucional, o qual aponte seu objeto e sua diferenciação.

\footnotetext{
${ }^{11}$ SILVA, Tagore Trajano de Almeida. Direito animal e ensino jurídico: formação e autonomia de um saber póshumanista. Salvador: Evolução, 2014. p. 51-52.

${ }^{12}$ Disponivel em: https://portalseer.ufba.br/index.php/RBDA. Acesso em: 10 out. 2019.

${ }^{13}$ Disponível

em: https://sucupira.capes.gov.br/sucupira/public/consultas/coleta/veiculoPublicacaoQualis/listaConsultaGeralPeri odicos.jsf. Acesso em: 22 abr. 2020.

${ }^{14}$ Disponível em: http://www.direito.ufpr.br/portal/animaiscomdireitos/wp-content/uploads/2019/09/cartade-sergipe.pdf. Acesso em: 10 out. 2019.

${ }^{15}$ Obviamente que, nesse contexto, a palavra animalismo nada tem a ver com o viés pejorativo, e de crítica política, adotada por George Orwell, em seu clássico literário, Revolução dos Bichos (Animal Farm), de 1945 (ORWELL, George. Revolução dos bichos. Tradução de Heitor Aquino Ferreira. São Paulo: Globo, 2003. p. 1825).
}

110 |Revista do Programa de Pós-Graduação em Direito da UFBA, e-issn 2358-4777, v. 30, n. 01, p.106 -136, Jan-Jun 2020 
Pode-se dizer que a proposta é de um conceito ontológico, que procure estabelecer o ser do Direito Animal, dentro da constelação de ramos jurídicos, conferindo-lhe uma unidade e, ao mesmo tempo, meios de diferenciação.

Nesse contexto, o Direito Animal pode ser conceituado como "o conjunto de regras e princípios que estabelece os direitos fundamentais dos animais não-humanos, considerados em si mesmos, independentemente da sua função ambiental ou ecológica." ${ }^{16}$

Para melhor precisar e justificar o conceito proposto, passa-se à sua desconstrução analítica:

\section{O Direito Animal é o [...]}

1) conjunto de regras e princípios [...]: trata-se de conceito ontológico e dogmático, forjado do ponto de vista do direito positivo, o que justifica a referência inicial ao conjunto normativo.

Regras e princípios são espécies de normas jurídicas, ${ }^{17}$ constituindo-se como normas jurídicas de primeiro grau, pois são as que servem de comandos para determinar condutas obrigatórias, permitidas e proibidas, ou condutas cuja adoção seja necessária para atingir determinados fins, e constituem o objeto da aplicação. ${ }^{18}$

Segundo Humberto Ávila,

regras são normas imediatamente descritivas, primariamente retrospectivas e com pretensão de decidibilidade e abrangência, para cuja aplicação se exige a avaliação da correspondência, sempre centrada na finalidade que thes dá suporte ou nos princípios que são axiologicamente sobrejacentes, entre a construção conceitual da descrição normativa e construção conceitual dos fatos. (grifo nosso). ${ }^{19}$

O autor mesmo afirma que, por sua vez,

princípios são normas imediatamente finalísticas, primariamente prospectivas e com pretensão de complementaridade e de parcialidade, para cuja aplicação se demanda uma avaliação da correlação entre o estado de coisas a ser promovido e os efeitos decorrentes da conduta havida como necessária à sua promoção. ${ }^{20}$

Ávila não concebe os princípios como mandados ou deveres de otimização, na forma preconizada, originalmente, por Alexy. ${ }^{21}$ Para ele, "a diferença entre princípios e regras não está no fato de que as regras devam ser aplicadas no todo e os princípios só na medida máxima.

\footnotetext{
${ }^{16}$ Esse conceito foi proposto em publicação nossa, no ano de 2018 , sem a desconstrução analítica realizada no presente artigo (ATAIDE JUNIOR, Vicente de Paula. Introdução ao Direito Animal brasileiro. Revista Brasileira de Direito Animal, Salvador, v. 13, n. 3, p. 48-76, set./dez. 2018. p. 50-51).

${ }^{17}$ Nesse sentido: ALEXY, Robert. Teoria dos direitos fundamentais. Tradução de Virgílio Afonso da Silva. 2. ed. São Paulo: Malheiros, 2017. p. 86-87.

18 ÁVILA, Humberto Bergmann, op. cit., p. 179. O mesmo autor aponta que, a par delas, existem as normas jurídicas de segundo grau - conhecidas como postulados -, as quais são metanormas, ou seja, normas jurídicas sobre a aplicação de outras normas (op. cit., p. 164), dentre as quais se destacam os postulados da razoabilidade e da proporcionalidade (op. cit., p. 185).

${ }^{19}$ Op. cit., p. 102.

${ }^{20}$ Op. cit., p. 102.

21 “O ponto decisivo na distinção entre regras e princípios é que princípios são normas que ordenam que algo seja realizado na maior medida possível dentro das possibilidades jurídicas e fáticas existentes. Princípios são, por conseguinte, mandados de otimização,[...]." (ALEXY, Robert, op. cit., p. 90).
}

111 Revista do Programa de Pós-Graduação em Direito da UFBA, e-issn 2358-4777, v. 30, n. 01, p.106 - 136, Jan-Jun 2020 
Ambas as espécies de normas devem ser aplicadas de tal modo que seu conteúdo de dever-ser seja realizado totalmente."22

Em síntese, segundo a teoria de Humberto Ávila, tanto regras quanto princípios impõem ou permitem comportamentos, sendo que as regras desde logo descrevem tais comportamentos, enquanto que os princípios permitem deduzir tais comportamentos a partir da definição do estado de coisas a ser promovido. ${ }^{23}$

Também é importante apontar que, segundo o mesmo autor, "toda norma jurídica inclusive as regras - só tem seu conteúdo de sentido e sua finalidade subjacente definidos mediante um processo de ponderação." ${ }^{24}$ Portanto, no conflito normativo, também as regras podem exigir ponderação, o que afasta Ávila de Dworkin e Alexy. ${ }^{25}$

2) [...] que estabelece os direitos fundamentais [...]: as normas jurídicas de primeiro grau regras e princípios - do Direito Animal estabelecem e disciplinam direitos fundamentais, ${ }^{26}$ os

\footnotetext{
${ }^{22}$ ÁVILA, Humberto Bergmann, op. cit., p. 86.
}

${ }^{23}$ Nesse ponto, é nítida a divergência teórica entre Humberto Ávila e Lenio Streck. Para este, "não se pode partir do princípio para resolver um caso. Isso seria fazer raciocínios teleológicos. Haverá uma regra (norma em geral) apta para resolver o caso a partir de uma reconstrução principiológica (reconstrução da história institucional). Esse é o espaço e o papel dos princípios." (op. cit., p. 580-581). Ávila fala em eficácia interna direta dos princípios, pela qual "os princípios exercem uma função integrativa, na medida em que justificam agregar elementos não previstos em subprincípios ou regras. Mesmo que um elemento inerente ao fim que deve ser buscado não esteja previsto, ainda assim o princípio irá garanti-lo. Por exemplo, se não há regra expressa que oportunize a defesa ou a abertura de prazo para manifestação da parte no processo - mas elas são necessárias -, elas deverão ser garantidas com base direta no princípio do devido processo legal." (op. cit., p. 123). Não obstante, Ávila também aponta que "Os princípios consistem em normas primariamente complementares e preliminarmente parciais, na medida em que, sobre abrangerem apenas parte dos aspectos relevantes para uma tomada de decisão, não têm a pretensão de gerar uma solução específica, mas de contribuir, ao lado de outras razões, para a tomada de decisão." (op. cit., p. 100).

${ }^{24}$ Op. cit., p. 110. Essa, talvez, seja a principal distinção da teoria dos princípios jurídicos de Humberto Ávila, em comparação com as teorias de Dworkin e Alexy. Para esses autores, os princípios se aplicam mediante ponderação com outros (sopesamento concreto entre razões colidentes, com atribuição de peso maior a uma delas), enquanto que as regras se aplicam mediante subsunção. Para Dworkin, a subsunção, atinente às regras, se dá no modo tudo ou nada (all-or-nothing), ou seja, "Dados os fatos que uma regra estipula, então ou a regra é válida, e neste caso a resposta que ela fornece deve ser aceita, ou não é válida, e neste caso em nada contribui para a decisão." (DWORKIN, Ronald. Levando os direitos a sério. Tradução Nelson Boeira. 3. ed. São Paulo: WMF Martins Fontes, 2010. p. 39). Para Alexy, "Já as regras são normas que são sempre ou satisfeitas ou não satisfeitas" (op. cit., p. 91), sendo que, "um conflito entre regras somente pode ser solucionado se se introduz, em uma das regras, uma cláusula de exceção que elimine o conflito, ou se pelo menos uma das regras for declarada inválida." (op. cit., p. 92).

${ }^{25}$ Em apertada síntese, para demonstrar que as regras também são ponderáveis, Humberto Ávila aponta casos em que elas, no plano abstrato, não perdem sua validade e a solução para o conflito se dá no plano concreto, com a atribuição de peso maior a uma delas, levando em consideração a finalidade que cada uma visa a preservar (op. cit., p. 74-75). Além disso, aponta que as regras também podem ter seu conteúdo preliminar de sentido superado por razões contrárias, mediante um processo de ponderação de razões. Assim, as exceções ao cumprimento da regra também partem de um sopesamento de razões: em função de uma razão contrária que supera axiologicamente a razão que fundamenta a própria regra, decide-se criar uma exceção (op. cit., p. 76-77). Dessa forma, a ponderação como processo para decidir um conflito normativo não pode ser critério distintivo entre regras e princípios, ainda que o tipo de ponderação de cada uma possa ser diferente (op. cit., p. 81).

${ }^{26}$ Segundo Robert Alexy, "a distinção entre regras e princípios é uma das colunas-mestras do edifício da teoria dos direitos fundamentais" (op. cit, p. 85). Humberto Ávila, por sua vez, fala em eficácia externa subjetiva dos princípios jurídicos, os quais "funcionam como direitos subjetivos quando proíbem as intervenções do Estado em direitos de liberdade, qualificada também como função de defesa ou de resistência (Abwehrfunktion)" e, também, "mandam tomar medidas para a proteção dos direitos de liberdade, qualificada também de função protetora (Schutzfunktion). Ao Estado não cabe apenas respeitar os direitos fundamentais, senão também o 
quais, de forma simples e objetiva, são os direitos reconhecidos e previstos como tais em determinada Constituição ${ }^{27}$ e que têm a função precípua de reforçar a proteção da dignidade da pessoa humana ${ }^{28}$ ou da dignidade de qualquer ser considerado, por essa mesma Constituição, como um fim em si mesmo. ${ }^{29} \mathrm{O}$ Direito Animal trabalha com direitos fundamentais, inaugurando uma nova dimensão desses direitos, como se verá a seguir.

3) [...] dos animais não-humanos [...]: o objeto do Direito Animal são os direitos fundamentais dos animais não-humanos. São direitos zoocêntricos, ${ }^{30}$ situados em uma nova dimensão ${ }^{31}$ dos direitos fundamentais: a quarta dimensão ${ }^{3233}$ ou direitos fundamentais póshumanistas. $^{34}$

dever de promovê-los por meio da adoção de medidas que os realizem da melhor forma possível." (op. cit., p. 128).

${ }^{27}$ ALEXY, Robert, op. cit., p. 69; SARLET, Ingo Wolfgang. A eficácia dos direitos fundamentais: uma teoria geral dos direitos fundamentais na perspectiva constitucional. 12. ed. Porto Alegre: Livraria do Advogado, 2015. p. 29.

${ }^{28}$ HÄBERLE, Peter. A dignidade humana como fundamento da comunidade estatal. In: SARLET, Ingo Wolfgang (org.). Dimensões da dignidade: ensaios de filosofia do direito e direito constitucional. 2. ed. Porto Alegre: Livraria do Advogado Editora, 2013. p. 75, 81-83.

${ }_{29}$ É sabido que, na fundamentação da metafísica dos costumes, Kant atribui dignidade apenas aos seres humanos, como seres racionais (KANT, Immanuel. Fundamentação da metafísica dos costumes. Tradução de Inês A. Lohbauer. São Paulo: Martin Claret, 2018. p. 70-78). No entanto, de lá para cá, a noção de dignidade foi ampliada para além do humano, numa perspectiva pós-humanista. Sobre esse tema, o qual, pela sua amplitude, transborda os limites da presente investigação, ver: MOLINARO, Carlos Alberto; MEDEIROS, Fernanda Luiz Fontoura de; SARLET, Ingo Wolfgang, FENSTERSEIFER, Tiago (coords). A dignidade da vida e os direitos fundamentais para além dos humanos: uma discussão necessária. Belo Horizonte: Editora Fórum, 2008.

${ }^{30}$ São direitos fundamentais centrados nas características e peculiaridades dos animais não-humanos.

${ }^{31}$ Segundo a teoria constitucional tradicional, direitos fundamentais são direitos de animais humanos. Nesse sentido, de acordo com a classificação que leva em conta o aparecimento histórico desses direitos, os direitos fundamentais de primeira dimensão são os direitos civis ou políticos (direitos de liberdade); os de segunda dimensão são os direitos econômicos, sociais e culturais (direitos de igualdade); os de terceira dimensão são os direitos de solidariedade e fraternidade, de caráter transindividual, dentre os quais o direito ao meio ambiente ecologicamente equilibrado (SARLET, Ingo Wolfgang, op, cit., p. 45-52; SCHÄFER, Jairo. Classificação dos direitos fundamentais: do sistema geracional ao sistema unitário: uma proposta de compreensão. 3. ed. Porto Alegre: Livraria do Advogado, 2018. p. 31-64).

32 Quarta dimensão, se considerarmos, segundo a teoria constitucional acima apontada, apenas as três dimensões já reconhecidas dos direitos fundamentais dos animais humanos. Será de sexta dimensão, se considerarmos, além das três já consolidadas pela teoria tradicional, duas outras dimensões, as quais, porém, não contam com ampla aceitação doutrinária: conforme a teoria do Prof. Paulo Bonavides, os direitos fundamentais de quarta dimensão seriam os direitos à democracia, à informação e ao pluralismo e os direitos fundamentais de quinta dimensão diriam respeito ao direito à paz (BONAVIDES, Paulo. Curso de direito constitucional. 27. ed. São Paulo: Malheiros, 2012. p. 589-591; 598-613). Zulmar Fachin e Deise Marcelino da Silva defendem que o direito fundamental à água potável seria direito fundamental de sexta dimensão (FACHIN, Zulmar; SILVA, Deise Marcelino da. Acesso à água potável: direito fundamental de sexta dimensão. Campinas: Millennium Editora, 2010). Não nos parece, no entanto, que o direito à água potável se desligue do direito ao meio ambiente ecologicamente equilibrado para compor uma nova dimensão de direitos fundamentais. Direitos fundamentais para além do ser humano (direitos fundamentais pós-humanistas) parecem melhor constituir a mais nova dimensão dos direitos fundamentais (a quarta ou sexta dimensão, a depender da classificação adotada).

${ }^{33}$ ATAIDE JUNIOR, Vicente de Paula, op. cit., p. 51.

${ }^{34}$ SILVA, Tagore Trajano de Almeida, op. cit., p. 33-42.

113 |Revista do Programa de Pós-Graduação em Direito da UFBA, e-issn 2358-4777, v. 30, n. 01, p.106 - 136, Jan-Jun 2020 
O importante é apontar que os direitos fundamentais de quarta dimensão estão implícitos na Constituição Federal de 1988, por influência dos avanços anteriores obtidos no plano internacional. ${ }^{35}$

Segundo o art. 225, § 1ํ, VII da Constituição, incumbe ao Poder Público "proteger a fauna e a flora, vedadas, na forma da lei, as práticas que coloquem em risco sua função ecológica, provoquem a extinção de espécies ou submetam os animais a crueldade."

Desse dispositivo constitucional extrai-se a regra da proibição da crueldade contra animais: estão proibidos os comportamentos humanos que submetam animais não-humanos à crueldade. Como a norma privilegia o elemento descritivo, de caráter negativo (proibição), tratase, nesse caso, de regra. ${ }^{36}$

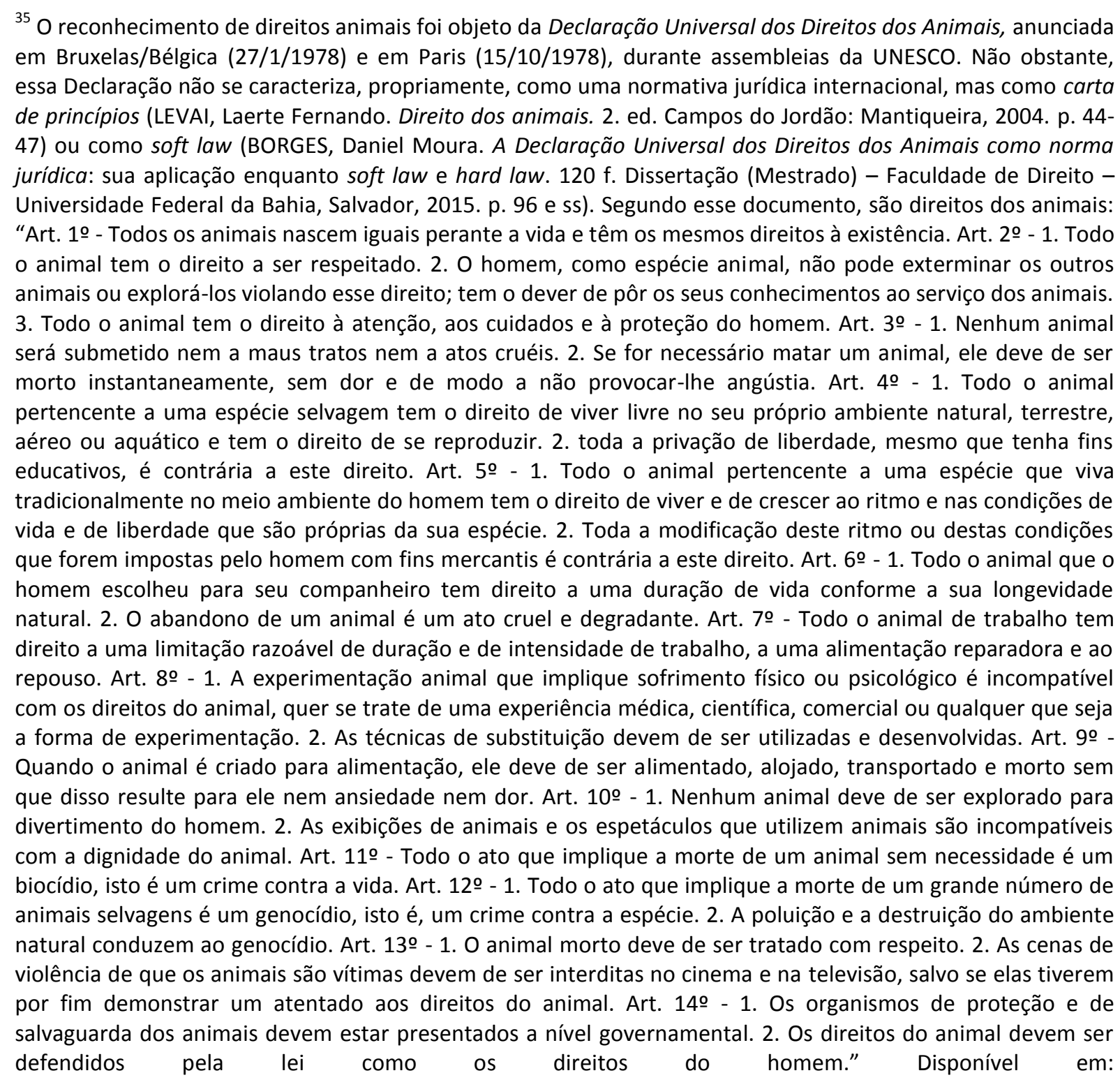
https://portal.cfmv.gov.br/uploads/direitos.pdf. Acesso em: 3 ago. 2018.

${ }^{36}$ Segundo Humberto Ávila, "Quando o caráter descritivo de determinado comportamento for privilegiado pelo legislador, o intérprete está diante de uma regra que, como tal, deve ser aplicada, mediante um exame de correspondência entre a construção conceitual dos fatos e a construção conceitual da norma e da finalidade que Ihe dá suporte, [...]." (op. cit., p. 64). No mesmo sentido: LOURENÇO, Daniel Braga; OLIVEIRA, Fábio Corrêa Souza de. Vedação da crueldade contra animais: regra ou princípio constitucional? Revista de Direito Fundamentais \& Democracia, v. 24, n. 2, p. 222-252, maio/ago. 2019. Disponível em: https://revistaeletronicardfd.unibrasil.com.br/index.php/rdfd/article/view/1294/590. Acesso em: 2 abr. 2020. 
Proíbe-se a crueldade porque se pressupõe que os animais são seres sencientes, ou seja, capazes de sofrer. ${ }^{37}$ Não haveria sentido em se proibir a crueldade contra coisas inanimadas, destituídas da capacidade de sentir dor ou de serem impactadas pela crueldade. ${ }^{38} \mathrm{O}$ fato senciência, portanto, está implicitamente reconhecido pela Constituição.

Assim, ainda que, filosoficamente, se possa discutir qual seria o melhor fundamento para direitos animais, ${ }^{39}$ é certo que, no Brasil, o Direito Animal se fundamenta na senciência animal. ${ }^{40}$

Ao valorar positivamente a senciência animal, proibindo as práticas cruéis, a Constituição brasileira considerada os animais não-humanos como seres importantes por si próprios, os considera como fins em si mesmos, ou seja, reconhece, implicitamente, a dignidade animal.

Nesse sentido, a Ministra Rosa Weber, do Supremo Tribunal Federal, afirmou, em julgamento, que

A Constituição, no seu artigo 225, § 1ำ, VII, acompanha o nível de esclarecimento alcançado pela humanidade no sentido de superação da limitação antropocêntrica que coloca o homem no centro de tudo e todo o resto como instrumento a seu serviço, em prol do

\footnotetext{
${ }^{37}$ As evidências sobre a senciência dos animais não-humanos já foram objeto de contemporâneas pesquisas empíricas, afastando a concepção cartesiana do animal-máquina (DESCARTES, René. Discurso do método. Porto Alegre: L\&PM, 2009. p. 79-99; FELIPE, Sonia Teresinha. Por uma questão de princípios: alcance e limites da ética de Peter Singer em defesa dos animais. Florianópolis: Fundação Boiteux, 2003. p. 53-62). Segundo a Declaração de Cambridge sobre a Consciência em Animais Humanos e Não Humanos (2012) - elaborado por neurocientistas, neurofarmacologistas, neurofisiologistas, neuroanatomistas e neurocientistas computacionais cognitivos reunidos na Universidade de Cambridge -, "A ausência de um neocórtex não parece impedir que um organismo experimente estados afetivos. Evidências convergentes indicam que os animais não humanos têm os substratos neuroanatômicos, neuroquímicos e neurofisiológicos de estados de consciência juntamente como a capacidade de exibir comportamentos intencionais. Consequentemente, o peso das evidências indica que os humanos não são os únicos a possuir os substratos neurológicos que geram a consciência. Animais não humanos, incluindo todos os mamíferos e as aves, e muitas outras criaturas, incluindo polvos, também possuem esses substratos neurológicos." Conferir o texto original, em inglês, disponível em: http://fcmconference.org/img/CambridgeDeclarationOnConsciousness.pdf. Acesso em: 4. abr. 2018.

${ }^{38}$ Segundo Gary Francione, "É importante reconhecer que a observação de que os animais são sencientes é diferente de dizer que eles são meramente vivos. Ser senciente significa ser do tipo de ser que é consciente da dor e do prazer; existe um 'eu' que tem experiências subjetivas. Nem tudo que está vivo é necessariamente senciente; por exemplo, que nós saibamos, as plantas, que são vivas, não sentem dor." (FRANCIONE, Gary Lawrence. Introdução aos direitos animais: seu filho ou o cachorro? Tradução de Regina Rheda. Campinas: Editora Unicamp, 2013. p. 55).

${ }^{39}$ O material já publicado, principalmente em língua inglesa, sobre a filosofia e ética animais é inesgotável. Mas, dois autores - e duas obras - costumam ser indicados como os representantes dos principais movimentos filosóficos-animalistas: Peter Singer, líder do benestarismo, a partir do livro Libertação Animal, publicado em 1975; e Tom Regan, expoente do abolicionismo, a partir do livro The Case for Animal Rights, publicado em 1983. Mas não pode deixar de ser citado o abolicionismo radical de Gary Francione, já nos anos 90 , principalmente a partir da obra Animals, Property and the Law, de 1995. Mais recentemente, uma postura intermediária, a partir da teoria política, pode ser encontrada com Sue Donaldson e Will Kimlicka, em seu Zoopolis: a Political Theory of Animal Rights, de 2011. Da produção original em língua portuguesa, vale a pena consultar as obras A Hora dos Direitos dos Animais, do professor lusitano Fernando Araújo, de 2003, que aborda as principais discussões filosóficas sobre os animais, com ampla varredura de quase tudo o que se escreveu sobre o assunto até então, e Direito dos Animais: Fundamentação e Novas Perspectivas, de 2008, do professor brasileiro Daniel Braga Lourenço, que também procede a um alentado levantamento das premissas filosóficas do Direito Animal.

40 MAROTTA, Clarice Gomes. Princípio da dignidade dos animais: reconhecimento jurídico e aplicação. Belo Horizonte: Editora D’Plácido, 2019. p. 107.
}

115 |Revista do Programa de Pós-Graduação em Direito da UFBA, e-issn 2358-4777, v. 30, n. 01, p.106 - 136, Jan-Jun 2020 
reconhecimento de que os animais possuem uma dignidade própria que deve ser respeitada. ${ }^{41}$

Portanto, para o Direito Animal, o animal não-humano é relevante enquanto indivíduo, portador de valor e dignidade próprios, dada a sua capacidade de sentir dor e experimentar sofrimento, seja físico, seja psíquico. É o fato da senciência animal, valorado pela Constituição, que revela a dignidade animal, incompatível com as equiparações tradicionais entre animais e coisas, animais e bens ou com a consideração dos animais como simples meios para o uso arbitrário desta ou daquela vontade humana.

Em outras palavras, o Direito Animal opera com a transmutação do conceito civilista de animal como coisa, para o conceito animalista de animal como sujeito de direitos. ${ }^{42}$

E, como sempre deve acontecer, toda dignidade é protegida por direitos fundamentais: ${ }^{43}$ a dignidade animal é a base axiológica dos direitos fundamentais animais (quarta dimensão dos direitos fundamentais), objeto do Direito Animal.

Como os direitos fundamentais animais são direitos individuais, atribuíveis a cada animal em si, constituem cláusula constitucional pétrea, ${ }^{44}$ não podendo ser objeto de deliberação qualquer proposta de emenda constitucional tendente a aboli-los (art. 60, § 4ㅇ, IV, Constituição).

${ }^{41}$ STF, Pleno, ADI 4983, Relator Ministro MARCO AURÉLIO, julgado em 06/10/2016, publicado em 27/04/2017. O Direito Animal se consolida, no plano jurisprudencial, a partir do julgamento, no final de 2016, da Ação Direta de Inconstitucionalidade 4983 (ADIn da vaquejada), pelo Supremo Tribunal Federal (STF). Ainda que outros precedentes da mesma Corte já tivessem proibido certas práticas humanas cruéis contra animais, como a "farra do boi" e as "rinhas de galos", esse foi o marco histórico da autonomia do Direito Animal e da sua separação epistemológica em relação ao Direito Ambiental.

${ }^{42}$ A Áustria foi pioneira em incluir, no seu Código Civil, em 1988, um dispositivo afirmando que os animais não são coisas (tiere sind keine sachen), protegidos por leis especiais (§285a ABGB); no mesmo sentido, em 1990, foi inserido o §90a no BGB alemão; em 2003, também no art. 641a do Código Civil suíço; de forma diferenciada foi a alteração do Código Civil francês, em 2015, dispondo, em seu art. 515-14, que os animais são seres vivos dotados de sensibilidade (Les animaux sont des êtres vivants doués de sensibilité.); na mesma linha do direito francês, mudou o Código Civil português, em 2017, estabelecendo que os animais são seres vivos dotados de sensibilidade e objeto de proteção jurídica em virtude da sua natureza (art. 201ㅇ-B). No Brasil tramitam, no Congresso Nacional, vários projetos de lei com o objetivo de conferir novo status jurídico aos animais. Dentre outros, o mais avançado é o Projeto de Lei da Câmara 27/2018 (no do Senado), oriundo do Projeto de Lei da Câmara 6799/2013 (no da Câmara), de autoria do Deputado Ricardo Izar, o qual estabelece que "Os animais não humanos possuem natureza jurídica sui generis e são sujeitos com direitos despersonificados, dos quais devem gozar e, em caso de violação, obter tutela jurisdicional, vedado o seu tratamento como coisa" (art. 3ㅇ). Esse projeto já foi aprovado na Câmara e no Senado, mas, como recebeu emenda aditiva no Senado (foi incluído um parágrafo único ao art. 3ㅇ: "A tutela jurisdicional referida no caput não se aplica ao uso e à disposição dos animais empregados na produção agropecuária e na pesquisa científica nem aos animais que participam de manifestações culturais registradas como bem de natureza imaterial integrante do patrimônio cultural brasileiro, resguardada a sua dignidade."), retornou à Câmara para análise da modificação. Note-se que, pelo projeto, todos os animais passam a ser considerados sujeitos de direitos, ainda que sem personalidade jurídica, não podendo mais ser tratados como coisas, modificando a interpretação comumente dada ao Código Civil brasileiro. Não obstante, conforme emenda aprovada no Senado, alguns animais não poderão gozar e obter a tutela jurisdicional dos seus direitos, exceção essa, no entanto, frontalmente inconstitucional, pois viola a garantia do acesso à justiça, conforme art. 5ㅇ, XXXV, da Constituição. A emenda do Senado, aliás, expressamente reconhece a dignidade animal. Por essas razões, espera-se que esse projeto seja definitivamente aprovado, sancionado e promulgado, preferencialmente sem a inconstitucional emenda senatorial, eliminando eventuais dúvidas sobre a existência de direitos fundamentais de quarta dimensão. Texto final aprovado disponível em: http://www.direito.ufpr.br/portal/animaiscomdireitos/wpcontent/uploads/2019/08/parecer-198-2019.pdf. Acesso em: 17 out. 2019.

${ }^{43}$ HÄBERLE, Peter, op. cit., loc. cit.

44 SARLET, Ingo Wolfgang; FENSTERSEIFER, Tiago. Direito constitucional ambiental: Constituição, direitos fundamentais e proteção do ambiente. 5. ed. São Paulo: RT, 2017. p. 83-84.

116 |Revista do Programa de Pós-Graduação em Direito da UFBA, e-issn 2358-4777, v. 30, n. 01, p.106 -136, Jan-Jun 2020 
Do próprio dispositivo constitucional que proíbe a crueldade (e implicitamente reconhece o fato senciência e o valor dignidade animal) exsurge, desde logo, o direito fundamental animal geral à existência digna. É direito fundamental - e não apenas objeto de compaixão ou de tutela -, porquanto é resultado da personalização e positivação do valor básico ${ }^{45}$ inerente à dignidade animal.

Mas o direito positivo brasileiro infraconstitucional já contempla uma catalogação adequada desse mínimo de direitos fundamentais animais.

Além da legislação federal, o Direito Animal também é composto pela legislação estadual, municipal e distrital, dado que a Constituição, ao estabelecer a forma federativa de Estado, distribuiu competência legislativa concorrente entre União, Estados e Distrito Federal para legislar sobre fauna (art. 24, VI) e competência administrativa comum entre União, Estados, Distrito Federal e Municípios para preservar a fauna (art. 23, VII). ${ }^{46}$ E não se deve olvidar que os Municípios detêm competência legislativa suplementar à legislação federal e estadual (art. 30, II, Constituição), além de competência legislativa privativa para assuntos de interesse local (art. 30, I, Constituição). estadual.

Esse catálogo mínimo de direitos fundamentais animais é fornecido pela legislação

O Estado da Paraíba aprovou seu Código de Direito e Bem-Estar Animal (Lei Estadual $11.140 / 2018$, vigente desde 10/10/2018), ${ }^{47}$ bastante moderno e inovador, disciplinando diversos assuntos, afirmando que "os animais são seres sencientes e nascem iguais perante a vida" e que "o valor de cada animal deve ser reconhecido pelo Estado como reflexo da ética, do respeito e da moral universal, da responsabilidade, do comprometimento e da valorização da dignidade e diversidade da vida" (art. 20). ${ }^{48}$

Esse Código, com mais de cem artigos, prevê aplicação de suas disposições tanto para animais vertebrados, como para animais invertebrados (art. 1으, caput), universalizando o espectro de abrangência protetiva, como quer a Constituição Federal.

No art. 5o do Código de Direito e Bem-Estar Animal da Paraíba apresenta-se o catálogo mínimo de direitos fundamentais animais - uma primeira especificação legal os direitos fundamentais de quarta dimensão - com a explícita adoção da linguagem dos direitos, em destaque:

Art. 5․ Todo animal tem o direito:

I - de ter as suas existências física e psíquica respeitadas;

II - de receber tratamento digno e essencial à sadia qualidade de vida;

III - a um abrigo capaz de protegê-lo da chuva, do frio, do vento e do sol, com espaço suficiente para se deitar e se virar;

IV - de receber cuidados veterinários em caso de doença, ferimento ou danos psíquicos experimentados;

$\mathrm{V}$ - a um limite razoável de tempo e intensidade de trabalho, a uma alimentação adequada e a um repouso reparador.

\footnotetext{
${ }^{45}$ SARLET, Ingo Wolfgang, op. cit., p. 61-62.

${ }^{46} \mathrm{O}$ termo fauna, para fins da repartição das competências constitucionais, deve ser interpretado de forma ampla, para abranger todas as espécies animais, incluindo tanto a perspectiva ambiental, como a perspectiva animalista (Direito Ambiental e Direito Animal).

${ }^{47}$ Disponível em: http://sapl.al.pb.leg.br/sapl/sapl_documentos/norma_juridica/13016_texto_integral. Acesso em: 27 nov. 2018.

${ }^{48}$ Cf. ATAIDE JUNIOR, Vicente de Paula (coord.). Comentários ao Código de Direito e Bem-Estar Animal do Estado da Paraíba: a positivação dos direitos fundamentais animais. Curitiba: Juruá, 2019.
} 
Ao contrário do que se possa deduzir, esses direitos não são exclusivos dos animais paraibanos, mas são de titularidade universal, ${ }^{49}$ aplicáveis em todo o território nacional, dado que esse catálogo realiza um comando da Constituição Federal: o dever estatal de estabelecer os direitos fundamentais aptos para proteger a dignidade animal.

No Estado Federal, especialmente nas hipóteses de competência legislativa concorrente, o sistema jurídico é multicêntrico, mas as ordens jurídicas federal e estaduais devem estar em sintonia para a realização dos propósitos da Constituição Federal.

Inspirando-se nas propostas de Marcelo Neves, ${ }^{50}$ pode-se cogitar de um transconstitucionalismo ou de um translegalismo federativo entre ordens jurídicas internas, ${ }^{51}$ como forma de garantir a realização dos direitos fundamentais explícitos ou implícitos na Constituição Federal (como também nas Constituições Estaduais).

Assim, de acordo com essa nova teoria, quando um Estado-Membro avança em catalogar ou reforçar a proteção de direitos fundamentais, essa disciplina normativa pode ser invocada perante os Estados-Membros e o Distrito Federal, que ainda não legislaram a respeito, ou mesmo perante a própria União, quando ela ainda não observou o seu dever de editar normas gerais que viabilizem a realização desses direitos fundamentais.

Os Estados-Membros e o Distrito Federal ao legislarem, no âmbito da competência concorrente, sobre direitos fundamentais, não estão apenas a realizar a sua própria ordem jurídica parcial, mas a concretizar a ordem jurídica nacional.

Isso revela, portanto, a importância do Código de Direito e Bem-Estar Animal da Paraíba na positivação dos direitos fundamentais de quarta dimensão, que constituem o objeto do Direito Animal e justificam o conceito proposto. Trata-se, dessa maneira, de modelo legislativo a ser seguido pelas demais unidades da federação. ${ }^{52}$

Evidentemente, outras leis - federais, estaduais e/ou distritais -, poderão inovar o ordenamento jurídico animalista para ampliar o catálogo de direitos fundamentais animais. Mas, como decorrência do princípio da vedação ao retrocesso, ${ }^{53}$ esse catálogo mínimo de direitos

\footnotetext{
${ }^{49}$ Como se verá, ao se adentrar à análise do princípio constitucional da universalidade, a atribuição de direitos fundamentais animais poderá variar a depender do grau de interação e dependência com os seres humanos, sem que isso se caracterize em discriminação especista. Assim, por exemplo, o direito fundamental ao tratamento médico veterinário é garantido a todos os animais domésticos, mas se atribuirá aos animais silvestres apenas nas hipóteses em que haja algum tipo de interação com humanos: o animal silvestre não tem direito a veterinário enquanto inserido no seu habitat e submetido às adversidades naturais, num ambiente ecologicamente equilibrado. No entanto, quando um animal silvestre é atropelado em uma rodovia, o dano sofrido em razão de uma construção humana, Ihe outorga o direito fundamental ao atendimento médico veterinário, além de outros que possam decorrer do catálogo mínimo. A universalidade, como princípio constitucional, impede que animais, simplesmente pela espécie a que pertencem, sejam excluídos da proteção de direitos fundamentais.

${ }^{50}$ NEVES, Marcelo. Transconstitucionalismo. São Paulo: WMF Martins Fontes, 2009.

${ }^{51}$ Preferindo falar em transfederalismo, ver a tese de doutorado defendida por José Arthur Castillo de Macedo, intitulada Encruzilhadas do federalismo: transfederalismo, cooperação, constitucionalismo e democracia, perante o Programa de Pós-Graduação em Direito da Universidade Federal do Paraná (MACEDO, José Arthur Castillo de. Encruzilhadas do federalismo: transfederalismo, cooperação, constitucionalismo e democracia. Curitiba, 2018, 223 p. Tese [Doutorado em Direito] - Programa de Pós-Graduação em Direito da Universidade Federal do Paraná). Disponível em: https://acervodigital.ufpr.br/bitstream/handle/1884/63219/R\%20\%20T\%20-\%20JOSE\%20ARTHUR\%20CASTILLO\%20DE\%20MACEDO.pdf?sequence=1\&isAllowed=y. Acesso em: 2 abr. 2020.

52 ATAIDE JUNIOR, Vicente de Paula. Código de bem-estar animal da Paraíba deve servir de modelo para o Brasil. Consultor Jurídico (CONJUR). Disponível em: https://www.conjur.com.br/2018-dez-23/vicente-paulacodigo-paraiba-modelo-direito-animal. Acesso em: 24 dez. 2018.

53 SARLET, Ingo Sarlet, op. cit., p. 451 et seq.; BELCHIOR, Germana Parente Neiva. Fundamentos epistemológicos do Direito Ambiental. Rio de Janeiro: Lúmen Júris, 2017. p. 180-185.
}

118 |Revista do Programa de Pós-Graduação em Direito da UFBA, e-issn 2358-4777, v. 30, n. 01, p.106 -136, Jan-Jun 2020 
fundamentais animais, estabelecido pelo Código de Direito e Bem-Estar Animal da Paraíba, não pode ser reduzido.

Enfim, a tarefa da dogmática do Direito Animal é sistematizar esse catálogo de direitos fundamentais animais, estabelecendo os seus alcances e frutificando suas possibilidades. ${ }^{54}$

Os animais são sujeitos de direitos fundamentais: trata-se de direito posto no Brasil, quer na Constituição Federal, quer nas Constituições Estaduais e leis extravagantes correlatas.

O passo seguinte é trabalhar a adequada especialização desses direitos e sua efetiva proteção em juízo.

4) considerados em si mesmos, independentemente da sua função ambiental ou ecológica: conforme a explícita dicotomia constitucional (art. 225, § 1ํ, VII), quando o animal não-humano é considerado fauna, relevante pela sua função ecológica, como espécie, ele é objeto das considerações do Direito Ambiental. ${ }^{55}$ Por outro lado, quando o animal não-humano importa por si mesmo, é relevante enquanto indivíduo senciente, portador de valor e dignidade próprios, passa a ser objeto das considerações do Direito Animal. ${ }^{56}$

Dessa forma, Direito Animal e Direito Ambiental não se confundem. Constituem disciplinas separadas, embora compartilhem várias regras e princípios jurídicos, dado que ambos, o primeiro exclusivamente, e o segundo inclusivamente, tratam da tutela jurídica dos animais nãohumanos.

O Supremo Tribunal Federal (STF), guardião da adequada interpretação constitucional, já teve a oportunidade de manifestar o entendimento sobre a autonomia da regra da proibição da crueldade e sua desconexão com a preservação do meio ambiente. No julgamento da Ação Direta de Inconstitucionalidade 4983 (ADIn da vaquejada), no final de 2016, o STF, por meio do voto-vista vencedor do Ministro Luís Roberto Barroso, afirmou que

A vedação da crueldade contra animais na Constituição Federal deve ser considerada uma norma autônoma, de modo que sua proteção não se dê unicamente em razão de uma função ecológica ou preservacionista, e a fim de que os animais não sejam reduzidos à mera condição de elementos do meio ambiente. Só assim reconheceremos a essa vedação o valor eminentemente moral que o constituinte lhe conferiu ao propôla em benefício dos animais sencientes. Esse valor moral está na declaração de que o sofrimento animal importa por si só, independentemente do equilíbrio do meio ambiente, da sua função ecológica ou de sua importância para a preservação de sua espécie. ${ }^{57}$ (grifos nossos). ${ }^{58}$

\footnotetext{
54 Sue Donaldson e Will Kymlicka, em Zoópolis, propõe, de forma inédita, que o catálogo de direitos fundamentais animais seja atribuído de acordo com as relações e interações entre humanos e animais, utilizando, para isso, de elementos da teoria política: direitos de cidadania, para animais domesticados (domesticated animal citizens); direitos de soberania, para animais selvagens (wild animal sovereignty), e direitos de quase-cidadania, para animais selvagens liminares (liminal animal denizens) (op. cit., passim).

${ }^{55} \mathrm{Na}$ Constituição (parte do inciso VII do $\S 1^{\circ}$ do art. 225): "proteger a fauna e a flora, vedadas, na forma da lei, as práticas que coloquem em risco sua função ecológica" e as práticas que "provoquem a extinção de espécies."

${ }^{56} \mathrm{Na}$ Constituição (parte do inciso VII do $\S 1^{\circ}$ do art. 225): "proteger a fauna e a flora, vedadas, na forma da lei, as práticas que submetam os animais a crueldade."

${ }^{57}$ Eis a ementa do respectivo acórdão: "VAQUEJADA - MANIFESTAÇÃO CULTURAL - ANIMAIS -CRUELDADE MANIFESTA - PRESERVAÇÃO DA FAUNA E DA FLORA - INCONSTITUCIONALIDADE. A obrigação de o Estado garantir a todos o pleno exercício de direitos culturais, incentivando a valorização e a difusão das manifestações, não prescinde da observância do disposto no inciso VII do artigo 225 da Carta Federal, o qual
} 
A parte final do conceito proposto é indispensável para afirmar a autonomia do Direito Animal, especialmente em relação ao Direito Ambiental. Tem guarida na jurisprudência atual do Supremo Tribunal Federal. O Direito Animal se importa com os animais enquanto indivíduos dotados de dignidade própria, considerados em si mesmos, independentemente da sua relevância ambiental ou ecológica. Por isso, a importância da linguagem dos direitos fundamentais: os animais não-humanos têm direitos fundamentais decorrentes da Constituição Federal, catalogados em lei, os quais constituem o objeto do Direito Animal.

\section{Princípios do Direito Animal brasileiro}

Definiu-se como regra a norma jurídica que pode ser prontamente extraída do dispositivo constitucional brasileiro que proíbe a crueldade contra animais. Isso é importante, pois, como regra, tem pretensão terminativa de gerar uma solução específica para os conflitos ${ }^{59}$ envolvendo animais não-humanos, impedindo soluções judiciais discricionárias, que desprezem direitos

veda prática que acabe por submeter os animais à crueldade. Discrepa da norma constitucional a denominada vaquejada." (STF, Pleno, ADI 4983, Relator Ministro MARCO AURÉLIO, julgado em 06/10/2016, publicado em 27/04/2017).

${ }^{58}$ Mas, a tutela constitucional dos animais não-humanos, considerados em si mesmos, desperta uma série de reações políticas, especialmente por parte daqueles que lucram com a exploração animal em todas as suas formas. O grau de influência e mobilização do poder econômico - e do consequente poder político - da indústria da exploração animal bem pode ser visualizado por intermédio do efeito backlash à decisão da jurisdição constitucional do Supremo Tribunal Federal, que declarou a inconstitucionalidade de lei cearense que regulamentava a vaquejada. O julgamento pelo plenário da Suprema Corte brasileira se deu em 06/10/2016, mas o respectivo acórdão somente foi publicado em 27/04/2017. Após intensa cobertura jornalística e midiática, com mobilização dos respectivos setores, organizando passeatas e caravanas de "vaqueiros" em prol da "regularização" da atividade, o Congresso Nacional aprovou, em 06/06/2017 (apenas oito meses após o julgamento do STF), a Emenda Constitucional 96, pela qual foi introduzido o § 70 no art. 225 da Constituição, determinando que "Para fins do disposto na parte final do inciso VII do § 10 deste artigo, não se consideram cruéis as práticas desportivas que utilizem animais, desde que sejam manifestações culturais, conforme o $\S 1$ o do art. 215 desta Constituição Federal, registradas como bem de natureza imaterial integrante do patrimônio cultural brasileiro, devendo ser regulamentadas por lei específica que assegure o bem-estar dos animais envolvidos." Não é preciso muito para concluir pela inconstitucionalidade da Emenda Constitucional 96/2017. O poder de reforma constitucional conhece limitações materiais, consubstanciadas nas cláusulas pétreas do art. $60, \S 4$ 을 da Constituição, dentre as quais os direitos e garantias individuais. A regra da proibição da crueldade, prevista no art. $225, \S 10$, VII da Constituição, personificou o direito fundamental animal à existência digna (de quarta dimensão, pós-humanista), de natureza individual, posta a salvo de práticas humanas cruéis. Como direito fundamental individual, ainda que não-humano, é imune ao poder constituinte derivado. O processo legislativo da emenda constitucional sequer poderia ter sido iniciado. As práticas cruéis contra animais estão constitucionalmente interditadas. Não importa se a prática é desportiva, se é manifestação cultural, se é registrada como bem de natureza imaterial integrante do patrimônio cultural brasileiro ou se existe lei local regulamentando a atividade. Caso a prática implique em crueldade contra animais, está proibida pela ordem constitucional vigente, ainda que a lei local procure paliativos para reduzir a dor, a angústia e o sofrimento dos animais envolvidos. A prática cruel não comporta gradações. A crueldade é, de qualquer forma, incompatível com os valores adotados pela Constituição. No julgamento da ADIn 4983, o STF reconheceu, por meio de dados empíricos e veterinários, que a prática da vaquejada é intrinsecamente cruel, não havendo como existir vaquejada sem crueldade. Essa mesma conclusão poderá ser estendida a outras práticas similares à vaquejada - como os rodeios -, caso se constate, por dados empíricos e veterinários, que também são intrinsecamente cruéis. Ora, não há como alterar a natureza das coisas! Se a vaquejada é cruel, não há como criar regra - como a criada pela Emenda Constitucional 96 - simplesmente dizendo que não se considera cruel sob determinadas condições.

${ }^{59}$ ÁVILA, Humberto Bergmann, op. cit., p. 100-101. 
fundamentais, em favor de interesses econômicos, quase sempre carentes de fundamentação adequada. $^{60}$

A novidade é que desse mesmo dispositivo constitucional também podem ser extraídos os princípios jurídicos do Direito Animal: do mesmo texto da Constituição, além de regras, podemse extrair princípios.

A teoria dos princípios de Humberto Ávila permite isto: os enunciados normativos (os textos ou dispositivos normativos) têm caráter pluridimensional, ou seja,

os dispositivos que servem de ponto de partida para a construção normativa podem germinar tanto uma regra, se o caráter comportamental for privilegiado pelo aplicador em detrimento da finalidade que lhe dá suporte, como também podem proporcionar a fundamentação de um princípio, se o aspecto valorativo for autonomizado para alcançar também comportamentos inseridos noutros contextos. ${ }^{61}$

Em outras palavras, é possível a "coexistência das espécies normativas em razão de um mesmo dispositivo", com a dissociação entre regras e princípios em alternativas inclusivas e não mais em alternativas exclusivas, como acontece com a teoria tradicional. ${ }^{62}$

É importante relembrar que os princípios, pela teoria de Ávila, notabilizam-se pelo seu caráter teleológico, determinando, em primeira mão, um estado de coisas a ser preservado ou atingido, para o qual se prescrevem os comportamentos necessários à sua realização, "mesmo sem a descrição dianteira desses comportamentos." ${ }^{63}$

Isso implica em dizer que a doutrina, mais do que enumerar princípios, justificá-los ou apontar a sua fonte, tem a tarefa fundamental de estabelecer quais são esses comportamentos indispensáveis para a realização dos princípios, sem o que eles - os princípios - acabam diminuídos na sua função normativa, persistindo como mera exaltação de valores. ${ }^{64}$

Esse referencial teórico é fundamental para que o Direito Animal tenha uma principiologia própria, fundada na Constituição, deixando de se basear, apenas, em especulações filosóficas ou em manifestações compassivas.

É a partir do art. 225, $\S 1$ 으, da Constituição que podem ser elaborados, ao menos, quatro princípios jurídicos exclusivos do Direito Animal: o princípio da dignidade animal, o princípio da universalidade, o princípio da primazia da liberdade natural e o princípio da educação animalista. $^{65}$

\footnotetext{
${ }^{60}$ Ver, por exemplo, a análise sobre a impugnação judicial do Código de Direito e Bem-Estar Animal do Estado da Paraíba, disponível em: http://www.direito.ufpr.br/portal/animaiscomdireitos/wpcontent/uploads/2019/08/tjpb_suspende_parcialmente_o_codigo_de_d.pdf. Acesso em: 20 abr. 2020.

${ }^{61}$ ÁVILA, Humberto Bergmann, op. cit., p. 93-94.

62 ÁVILA, Humberto Bergmann, op. cit., p. 92.

63 ÁVILA, Humberto Bergmann, op. cit., p. 99.

${ }^{64}$ ÁVILA, Humberto Bergmann, op. cit., p. 87-88.

${ }^{65}$ Tagore Trajano de Almeida Silva elaborou a primeira proposta principiológica do Direito Animal brasileiro: princípios da dignidade animal, do antiespecismo, da não-violência e do veganismo (op. cit., p. 95). A proposta do presente ensaio compartilha com o referido autor o princípio da dignidade animal, mas procura elaborar os demais princípios com uma base mais aderente ao texto constitucional, sem a necessidade de se evocar ensinamentos ético-filosóficos. O propósito disso é conferir ao Direito Animal um conjunto de princípios com conteúdo normativo forte, de aplicabilidade viável em processos judiciais e padrão argumentativo dogmático. Isso não quer dizer que os demais princípios propostos por Tagore Trajano não tenham consistência científica. A ideia maior que norteia o presente trabalho é apresentar novas possibilidades, a partir de novos referenciais
} 
A ideia é apenas lançar uma proposta de princípios jurídicos animalistas.

Pelos limites de um artigo, não é possível ir muito mais longe. A lista apresentada não é exaustiva e as modalidades sugeridas devem ser objeto de crítica. Podem ser mais, mas dificilmente serão menos. Talvez devam ser de outra maneira. Mas, insista-se, não basta enumerá-los e indicar sua fonte normativa. É preciso ir adiante, apontar os seus propósitos e, ao menos, começar a imprescindível tarefa de apontar o seu conteúdo, com a catalogação dos comportamentos necessários para os realizar.

Além dos princípios típicos ou exclusivos do Direito Animal, porquanto normas jurídicas ligadas às singularidades desse novo campo jurídico, também podem ser apontados princípios originados de outras ramificações, mas que, por apresentarem propósitos conexos, são compartilhados com esse novo ramo do Direito. A lista, nesse caso, é infinita, de modo que, no âmbito deste ensaio preliminar, serão apontados apenas os mais relevantes.

É o caso, por exemplo, do princípio, imanente ao Direito Processual, do acesso à Justiça, estabelecido a partir do art. 5ㅇ, XXXV, da Constituição brasileira: quem tem direitos, tem o direito à proteção jurisdicional, em caso de lesão ou ameaça a esses mesmos direitos. Se animais têm direitos, têm direito de ir a juízo para os defender. O Direito Animal, compartilhando com o Direito Processual o princípio do acesso à justiça (ou princípio da inafastabilidade do controle jurisdicional), estabelecerá que os animais não-humanos, porquanto sujeitos de direitos, têm capacidade de ser parte e legitimação "ad causam" para demandar pelos seus direitos fundamentais, não podendo qualquer lei suprimir essas possibilidades.

Assim formulado, analisar-se-á cada proposta de princípio exclusivo separadamente, para, em capítulo posterior, tratar-se dos princípios compartilhados.

\subsection{Princípio da dignidade animal}

O princípio da dignidade animal está na base estrutural do Direito Animal, seja qual for a nacionalidade da ordem jurídica que o contemple. ${ }^{66}$ Não é possível falar em direitos fundamentais animais sem reconhecer um estatuto de dignidade próprio para os animais nãohumanos. No Brasil, esse princípio dimana do dispositivo constitucional que proíbe a crueldade contra animais, ${ }^{67}$ assentando que os animais também interessam por si mesmos, como seres sencientes, a despeito da sua relevância ecológica, não podendo ser reduzidos ao status de coisas, nem serem objetos da livre ou ilimitada disposição da vontade humana. ${ }^{68}$

Como todo princípio é teleológico e visa a estabelecer um estado de coisas que deve ser promovido, sem descrever diretamente, qual o comportamento devido, ${ }^{69}$ o princípio da dignidade animal tem, como conteúdo, a promoção do redimensionamento do status jurídico

teóricos, complementando o material doutrinário disponível e ensejando um juízo crítico mais amplo, que possa refinar a estrutura principiológica do Direito Animal.

${ }^{66}$ O Animal Welfare Act da Suíça - isto é, a Lei de Bem-Estar Animal da Suíça -, de 2005, por exemplo, é expresso em afirmar que o seu propósito é proteger a dignidade e o bem-animal (art. 1으). No seu art. 3으, $a$, define dignidade como o "valor inerente do animal, que deve ser respeitado ao se lidar com ele. Caso exista alguma tensão imposta ao animal que não possa ser justificada por interesses imperiosos, isso se constitui um desrespeito à dignidade do animal. A tensão é considerada presente, particularmente, se for infligido dor, sofrimento ou dano ao animal, se ele for exposto a ansiedade ou humilhação, se houver grande interferência em sua aparência ou habilidades, ou se for excessivamente instrumentalizado." (tradução livre). Disponível em: https://www.admin.ch/opc/en/classified-compilation/20022103/index.html. Acesso em: 17 abr. 2020.

67 O Município de Belo Horizonte/MG, por meio do Decreto 16.431/2016, ao estabelecer a sua política de defesa e proteção dos animais, incluiu o princípio da dignidade animal, "reconhecendo que o animal tem seu valor intrínseco e que a dignidade humana e a dignidade animal são inapartáveis" (art. 3o, IV). Disponível em: http://portal6.pbh.gov.br/dom/iniciaEdicao.do?method=DetalheArtigo\&pk=1169141. Acesso em: 20 abr. 2020.

${ }^{68}$ SILVA, Tagore Trajano de Almeida, op. cit., p. 100-103; MAROTTA, Clarice Gomes, op. cit., p. 106.

${ }^{69}$ ÁVILA, Humberto Bergmann, op. cit., p. 70. 
dos animais não-humanos, de coisas para sujeitos, impondo ao Poder Público e à coletividade comportamentos que respeitem esse novo status, seja agindo para proteger, seja abstendo-se de maltratar ou praticar, contra eles, atos de crueldade ou que sejam incompatíveis com a sua dignidade peculiar.

Com o princípio constitucional da dignidade animal, o Direito Animal vai além da proibição das práticas cruéis (vaquejadas, rinhas, etc.), para também disciplinar outras questões que dizem respeito a tal dignidade, mas que não envolvem, necessariamente, referidas práticas cruéis, a saber: criação, compra, venda, leilão e sorteio de animais, antropomorfização de animais de estimação, uso da imagem de animais, guarda e direito de visitas de animais de estimação (ao invés de partilha de bens), destinação adequada e respeitosa de restos mortais, etc. Nesse aspecto reside o seu significado pragmático, dando base a demandas e a decisões judiciais para a tutela jurídica da dignidade animal.

Como uma das principais consequências desse princípio constitucional, o Código Civil brasileiro, enquanto lei ordinária, precisa ser relido, conforme a Constituição, para afastar qualquer interpretação que resulte em atribuir aos animais o status jurídico de coisa, bem móvel ou bem semovente. ${ }^{70}$

Além disso, toda atividade humana, de natureza recreativa, de divertimento ou de lazer, que envolva animais, pode ser considerada, a priori, inconstitucional, por violar o princípio da dignidade animal. É por essa razão que a caça ${ }^{71}$ e a pesca amadora são inconstitucionais e sua proibição deve ser conseguida pela via administrativa ou judicial. ${ }^{72}$

Uma outra consequência relevante desse princípio é a exigência de estudo prévio de impacto ambiental, na forma do art. $225, \S 10$, IV , da Constituição, para instalação de obra ou atividade potencialmente causadora de significativa vulneração de direitos fundamentais

\footnotetext{
${ }^{70}$ Paulo Lôbo realiza uma das mais importantes incursões civilistas na análise da natureza jurídica dos animais, a partir do art. 225, § 10, VII da Constituição, da Declaração Universal dos Direitos Animais, dos julgamentos realizados pelo Supremo Tribunal Federal e da experiência estrangeira. Transparece da sua doutrina que o enquadramento jurídico dos animais não pode mais ser como bens semoventes (Direito civil. 7. ed. São Paulo: Saraiva Educação, 2018. v. 4. p. 17-18).

${ }^{71}$ DIAS, Edna Cardozo. A tutela jurídica dos animais. Belo Horizonte: Mandamentos, 2000. p. 107-109.

${ }^{72}$ Um importante precedente judicial nesse sentido emanou do Tribunal Regional Federal da 4a Região, ao proibir a caça amadora no Estado do Rio Grande do Sul: AMBIENTAL. CAÇA AMADORÍSTICA. EMBARGOS INFRINGENTES EM FACE DE ACÓRDÃO QUE, REFORMANDO A SENTENÇA DE PARCIAL PROCEDÊNCIA EM AÇÃO CIVIL PÚBLICA AJUIZADA COM VISTAS À VEDAÇÃO DA CAÇA AMADORISTA NO RIO GRANDE DO SUL, DEU PROVIMENTO ÀS APELAÇÕES PARA JULGAR IMPROCEDENTE A ACTIO. PRÁTICA CRUEL EXPRESSAMENTE PROIBIDA PELO INCISO VII DO $\S 1^{\circ}$ DO ART. 225 DA CONSTITUIÇÃO E PELO ART. 11 DA DECLARAÇÃO UNIVERSAL DOS DIREITOS DOS ANIMAIS, PROCLAMADA EM 1978 PELA ASSEMBLÉIA DA UNESCO, A QUAL OFENDE NÃO SÓ I. O SENSO COMUM, QUANDO CONTRASTADO O DIREITO À VIDA ANIMAL COM O DIREITO FUNDAMENTAL AO LAZER DO HOMEM (QUE PODE SER SUPRIDO DE MUITAS OUTRAS FORMAS) E II. OS PRINCÍPIOS DA PREVENÇÃO E DA PRECAUÇÃO, MAS TAMBÉM APRESENTA RISCO CONCRETO DE DANO AO MEIO AMBIENTE, REPRESENTADO PELO POTENCIAL TÓXICO DO CHUMBO, METAL UTILIZADO NA MUNIÇÃO DE CAÇA. PELO PROVIMENTO DOS EMBARGOS INFRINGENTES, NOS TERMOS DO VOTO DIVERGENTE. Com razão a sentença ao proibir, no condão do art. 225 da Constituição Federal, bem como na exegese constitucional da Lei n. - 5.197/67, a caça amadorista, uma vez carente de finalidade social relevante que lhe legitime e, ainda, ante à suspeita de poluição ambiental resultante de sua prática (irregular emissão de chumbo na biosfera), relatada ao longo dos presentes autos e bem explicitada pelo MPF. Ademais, i. proibição da crueldade contra animais art. $225, \S 1^{\circ}$, VII, da Constituição - e a sua prevalência quando ponderada com o direito fundamental ao lazer, ii. incidência, no caso concreto, do art. 11 da Declaração Universal dos Direitos dos Animais, proclamada em 1978 pela Assembléia da UNESCO, o qual dispõe que o ato que leva à morte de um animal sem necessidade é um biocídio, ou seja, um crime contra a vida e iii. necessidade de consagração, in concreto, do princípio da precaução. 3. Por fim, comprovado potencial nocivo do chumbo, metal tóxico encontrado na munição de caça. 4. Embargos infringentes providos. (TRF4, 2a Seção, EINF 2004.71.00.021481-2, Relator Desembargador Federal CARLOS EDUARDO THOMPSON FLORES LENZ, publicado em 02/04/2008).
}

123 |Revista do Programa de Pós-Graduação em Direito da UFBA, e-issn 2358-4777, v. 30, n. 01, p.106 - 136, Jan-Jun 2020 
animais silvestres ou domésticos. Não apenas o comprometimento da função ecológica da fauna ou a possibilidade de extinção de espécies animais deve ser levada em consideração nesse estudo, mas também a potencial submissão de animais a práticas cruéis decorrentes da obra ou da atividade. ${ }^{73}$

Por fim, é do princípio da dignidade animal que emana, para a União (art. 22, I, terceira figura e art. 23, VII, da Constituição brasileira), o mandado de criminalização ${ }^{74}$ dos maus-tratos a animais, hoje cumprido, em parte, pelo art. 32 da Lei $9.605 / 1998 .{ }^{75}$ Isso quer dizer que a criminalização das condutas ofensivas à dignidade animal não pode mais ser suprimida ou diminuída no seu potencial punitivo. ${ }^{76}$

\subsection{Princípio da universalidade}

O princípio da universalidade complementa o princípio da dignidade animal, estabelecendo a amplitude subjetiva do reconhecimento dos animais como sujeitos de direitos. ${ }^{77}$ O Direito Animal brasileiro é universal porque a Constituição não distingue quais espécies animais estão postas a salvo de práticas cruéis, como também o art. 32 da Lei 9.605/1998 não distingue de quais espécies animais podem ser os indivíduos vítimas do crime contra a dignidade animal, de maneira que a proteção constitucional e legal é universal. ${ }^{78}$ Todos os animais são $^{2}$ sujeitos do direito fundamental à existência digna. ${ }^{79} \mathrm{Com}$ isso, o princípio da universalidade quer

${ }^{73}$ O que impõe uma revisão da Resolução 1/1986, do Conselho Nacional do Meio Ambiente (CONAMA), que disciplina, até hoje, os estudos de impacto ambiental. Disponível em: http://www2.mma.gov.br/port/conama/res/res86/res0186.html. Acesso em: 29 abr. 2020.

${ }^{74}$ MORAES, Alexandre Rocha Almeida de. A teoria dos mandados de criminalização e o combate efetivo à corrupção. Revista Jurídica ESMP-SP, v. 5, p. 43-68, 2014. Disponível em: http://www.esmp.sp.gov.br/revista_esmp/index.php/RJESMPSP/article/download/170/65. Acesso em: 20 abr. 2020.

${ }^{75}$ MAROTTA, Clarice Gomes, op. cit., p. 82-83. Segundo o art. 32, da Lei 9.605/1998, "Praticar ato de abuso, maus-tratos, ferir ou mutilar animais silvestres, domésticos ou domesticados, nativos ou exóticos: Pena detenção, de três meses a um ano, e multa. § 1을 ou cruel em animal vivo, ainda que para fins didáticos ou científicos, quando existirem recursos alternativos. $\S$ 20 A pena é aumentada de um sexto a um terço, se ocorre morte do animal." Esse dispositivo legal cumpre apenas em parte o mandado de criminalização dos maus-tratos a animais, emanado da Constituição, pois as sanções penais previstas ainda são muito brandas, enquadrando tal crime como infração penal de menor potencial ofensivo (!), apurada no âmbito dos Juizados Especiais Criminais, conforme Lei 9.099/1995.

${ }^{76}$ MAROTTA, Clarice Gomes, op. cit., p. 82-83.

77 Segundo Heron José de Santana Gordilho, “Um dos principais problemas enfrentados pela teoria abolicionista do Direito Animal é determinar quais os animais estariam habilitados a ser sujeitos de direito, mesmo porque não existe um consenso na definição do direito animal. Além disso, existe um risco muito grande de essa teoria ser ridicularizada se formigas, mosquitos ou baratas passarem a integrar as relações jurídicas processuais." (GORDILHO, Heron José de Santana. Abolicionismo animal. Salvador: Evolução, 2008. p. 149).

78 Não obstante as dificuldades teóricas antes apresentadas por Heron Gordilho, as quais representariam obstáculos à adoção do princípio da universalidade, ele mesmo percebe que "As pessoas matam os insetos e os ratos porque eles picam ou provocam doenças, mas retirar as asas de um inseto apenas pelo prazer de vê-lo sofrer seria um ato de crueldade." (op. cit., p. 152).

${ }^{79}$ Como já se pode perceber, esse princípio jurídico é importante, dada à tendência dos filósofos da ética animal, sejam abolicionistas, sejam benestaristas, em privilegiar determinados grupos de animais para a proteção ético-jurídica, pelas suas características próprias, quase sempre pela sua maior proximidade com as características dos seres humanos. Peter Singer e Tom Regan, por exemplo, cada qual em um lado da ética animal, elegem mamíferos e aves, não obstante façam concessões aos peixes (SINGER, Peter, op. cit., p. 192198; REGAN, Tom. Jaulas vazias: encarando o desafio dos direitos animais. Tradução de Regina Rheda. Revisão técnica de Sônia T. Felipe e Rita Paixão. Porto Alegre: Lugano, 2006). Steven Wise elabora uma escala de autonomia prática, pelo qual classifica os seres não-humanos em grupos, conforme a pontuação relacionada ao 
promover a erradicação do especismo seletista, ou seja, das formas de preconceito e de discriminação pela espécie, mas que são dirigidas não a todas, mas a apenas algumas das espécies animais, ${ }^{80}$ como os animais submetidos à exploração pecuária e os animais usados em testagens ou em experimentações científicas. ${ }^{81}$

Mas, se o fundamento do Direito Animal brasileiro é a senciência, isso não significaria que ele abrange, apenas, os animais sencientes, excluindo os não-sencientes?

Como argumenta Gary Francione,

Pode ser que nem todos os animais sejam sencientes, e pode ser difícil traçar uma linha separando aqueles que são capazes de experienciar dor e sofrimento conscientemente daqueles que não são. Entretanto, não há dúvida de que a maioria dos animais que exploramos são sencientes. Embora possamos não saber se os insetos são capazes de experienciar conscientemente a dor, sabemos que os primatas, as vacas, os porcos, as galinhas e os roedores são sencientes e capazes de experiências mentais subjetivas. E o fato de que muitos peixes e outros animais marinhos também são sencientes é vastamente aceito pelos cientistas. ${ }^{82}$

Além disso, é oportuno lembrar que a Declaração de Cambridge sobre a Consciência em Animais Humanos e Não Humanos, de 2012, inclui na relação de seres sencientes e conscientes não apenas mamíferos e aves, mas, também "muitas outras criaturas, incluindo polvos", não descartando, portanto, os animais invertebrados. ${ }^{83}$

A universalidade se afirma diante da impossibilidade de exclusão, a priori, de espécies animais do âmbito da senciência. Consequentemente, diante da inexistência de prova científica sobre a senciência de determinada espécie animal, concede-se o benefício da dúvida, ${ }^{84}$ inclusive por decorrência do princípio compartilhado da precaução (ver adiante), impondo-se a proteção de seus indivíduos pelo Direito Animal.

seu estágio de autonomia prática, de maneira que os seres com maior pontuação, ou seja, com maior nível de consciência e de raciocínio, merecem mais direitos (WISE, Steven M. Animal rights, one step at a time. In: SUNSTEIN, Cass R.; NUSSBAUM, Martha Craven (org.). Animal rights: current debates and new directions. Oxford University Press, 2004. p. 19-50; sobre a escala de autonomia prática de Wise, ver: MIGLIORE, Alfredo Domingues Barbosa. Personalidade jurídica dos grandes primatas. Belo Horizonte: Del Rey, 2012. p. 246-250). Mas, certamente, são os primatas, com destaque aos chimpanzés e aos bonobos, pela sua similaridade genética e mental com os seres humanos, que desfrutam da preferência dos filósofos da ética animal para receberem direitos fundamentais (MIGLIORE, Alfredo Domingues Barbosa, ibidem, p. 255-257). É conhecido, nesse sentido, o Great Ape Project (Projeto Grandes Primatas), o qual, desde 1993, liderado pelos filósofos Peter Singer e Paola Cavalieri, postula a imediata extensão de direitos humanos para os grandes primatas (GORDILHO, Heron José de Santana, op. cit., p. 115-120).

${ }^{80}$ GORDILHO, Heron José de Santana, op. cit., p. 17.

${ }^{81}$ Cf. FRANCIONE, Gary Lawrence, Introdução aos direitos animais: seu filho ou o cachorro?, op. cit., p. 55.

82 Ibidem, p. 54.

${ }^{83}$ Como se viu, o Código de Direito e Bem-Estar Animal do Estado da Paraíba contempla, em seu art. 10, caput, também os animais invertebrados, sem distinções, atendendo ao princípio constitucional da universalidade.

${ }^{84}$ Nesse sentido, Peter Singer afirma que "Se os crustáceos podem sofrer, deve haver um grande sofrimento envolvido, não apenas no método pelo qual são mortos, mas também na maneira como são transportados e mantidos vivos nos mercados. Para mantê-los frescos, são, muitas vezes, simplesmente embalados vivos, uns sobre os outros. Portanto, mesmo que haja alguma dúvida quanto à capacidade destes animais sentir dor, o fato de que podem estar sofrendo muito, combinado com a ausência, de nossa parte, de qualquer necessidade de comê-los, torna o veredicto claro: eles devem receber o benefício da dúvida." (SINGER, Peter, op. cit., 197198).

125 |Revista do Programa de Pós-Graduação em Direito da UFBA, e-issn 2358-4777, v. 30, n. 01, p.106 - 136, Jan-Jun 2020 
Essa universalidade não significa, no entanto, que todos os animais devam ser tratados da mesma forma, sem levar em consideração as peculiaridades de cada espécie e as suas formas de interações com os seres humanos. É certo que quanto maior a interação e, em alguns casos, a dependência, com os seres humanos, maior deve ser o catálogo e a atribuição de direitos fundamentais, podendo-se chegar a direitos de cidadania para animais domésticos, como na proposta da Zoópolis, de Sue Donaldson e Will Kymlicka. ${ }^{85}$

Nessa mesma linha de pensamento, os animais silvestres, enquanto inseridos em seu habitat, sem interações imediatas com seres humanos, podem exigir direitos de soberania, para que suas comunidades naturais tenham mantidas as condições para a sustentação de seus processos ecológicos de vida. ${ }^{86}$

O mais importante no princípio da universalidade é deixar claro que a Constituição não faz distinções entre animais: todos os membros do Reino Animal têm dignidade própria e são considerados pelo Direito Animal. Todos podem ser vítimas do crime tipificado pelo art. 32 da Lei 9.605/1998. O catálogo e a atribuição de direitos fundamentais é que poderá variar a depender, precipuamente, da sua forma de interação e dependência com os seres humanos, dentro de uma realidade zoopolítica: essa especificação é a tarefa dogmática mais urgente da doutrina animalista.

Dessa forma, sendo universal, o Direito Animal estabelece direitos fundamentais aos 1) animais silvestres, os quais já gozam de uma tutela jurídica superior, que lhes confere, inclusive, os direitos à vida e à liberdade (art. 10, Lei 5.197/1967; art. 29, Lei 9.605/1998); 2) animais de estimação ou de companhia - especialmente, cães e gatos - que desfrutam não só de uma ampla gama de direitos reconhecidos, sobretudo por meio das legislações estaduais, municipais e distritais, como também gozam da maior eficácia social de seus direitos; é possível afirmar que o Direito Animal brasileiro deve sua existência - e constante ascensão - à comoção social que os maus-tratos a cães e gatos geralmente costuma produzir; 3) aos animais submetidos à exploração econômica pela pecuária e pela pesca - bois, vacas, porcos, galinhas, carneiros, bodes, coelhos além de variadas espécies de peixes, moluscos e crustáceos, para os quais a tarefa dogmática é ainda mais urgente, porque são esses animais os mais vulneráveis, os quais, ainda, não conseguiram alcançar o patamar mais inferior de efetividade dos seus direitos básicos de quarta dimensão; nessa posição também se encontram os animais sujeitos à exploração da força de trabalho - cavalos, jumentos, bois, etc. -, à sujeição a atividades culturais e de entretenimento humano - elefantes, tigres, macacos, leões, touros, cavalos, papagaios, etc. -, além dos animais submetidos, como cobaias, às experimentações científicas e às testagens de produtos - camundongos, coelhos, etc.

\subsection{Princípio da primazia da liberdade natural}

O princípio da primazia da liberdade natural também decorre da dignidade animal, na sua dimensão de liberdade, posta na Constituição Federal, mas tem especificação na legislação infraconstitucional federal.

\footnotetext{
${ }^{85}$ Op. cit., p. 101 et seq.

86 DONALDSON, Sue; KYMLICKA, Will, op. cit., p. 156 et seq. Os autores também destacam a especial consideração que merecem os animais liminares, dentre os quais se situam os animais sinantrópicos, os quais não são nem domesticados, nem silvestres, mas vivem em constante interação, e às vezes com estreita dependência, com os humanos. É o caso dos ratos, esquilos, pombas, gambás, raposas, esquilos, dentre outros, os quais não restam isolados na natureza (com direitos de soberania), mas, também, não se submetem à domesticação (com direitos de cidadania). Para os liminares, Donaldson e Kymlicka sugerem direitos de quasecidadania, pelos quais se garante a moradia entre nós, sem as exigências cooperativas da concidadania (op. cit., p. 210 et. seq.).
}

126 |Revista do Programa de Pós-Graduação em Direito da UFBA, e-issn 2358-4777, v. 30, n. 01, p.106 -136, Jan-Jun 2020 
Segundo o art. 25, § 1으, da Lei 9.605/1998 (Lei dos Crimes Ambientais), com a redação dada pela Lei 13.052/2014, "Os animais serão prioritariamente libertados em seu habitat ou, sendo tal medida inviável ou não recomendável por questões sanitárias, entregues a jardins zoológicos, fundações ou entidades assemelhadas, para guarda e cuidados sob a responsabilidade de técnicos habilitados." ${ }^{87}$

Esse princípio é aplicável, sobretudo, aos animais silvestres, os quais têm direito à vida e direito à liberdade natural. ${ }^{88}$

O estado de coisas a ser promovido por esse princípio é a integridade das comunidades de animais silvestres, colocando-as a salvo das intervenções humanas destrutivas, ${ }^{89}$ além de conduzir à progressiva extinção de zoológicos, aquários, fundações e entidades assemelhadas, enquanto estabelecimentos destinados à exploração animal.

Evidentemente, ressalvam-se aqui as entidades que recebem animais silvestres apreendidos pela fiscalização ambiental ou feridos por causas diversas, como os atropelados em rodovias para tratamento veterinário.

Mas, a atuação dessas entidades é ressalvada pela parte final do próprio art. $25, \S 10$ da Lei 9.605/1998. A importância do princípio da primazia da liberdade natural é exatamente impor que essas entidades engendrem todos os esforços possíveis para a reintegração do animal silvestre ao seu habitat ou, em caso de manifesta impossibilidade, comprovada e devidamente fundamentada em termos técnicos, que o novo ambiente a que se destine o animal possibilite a imitação, o tanto quanto possível, do respectivo habitat, inclusive quanto à natural socialização, quando for o caso de espécie social.

É o interesse animal, não o interesse humano, que deve preponderar na decisão sobre a destinação do animal cativo. Por essas razões, e pelo princípio em questão, devem ser melhor refletidas as decisões judiciais que permitem que animais silvestres, como papagaios, por estarem, por longos períodos, na convivência doméstica humana, como verdadeiros pets, permaneçam nessa reclusão, com a perda das suas chances de convivência natural com outros membros de sua espécie, ainda que em cativeiro regularmente estabelecido. ${ }^{90}$

\subsection{Princípio da educação animalista}

\footnotetext{
${ }^{87}$ A redação anterior do parágrafo era assim: "Os animais serão libertados em seu habitat ou entregues a jardins zoológicos, fundações ou entidades assemelhadas, desde que fiquem sob a responsabilidade de técnicos habilitados." Note-se que, nesse caso, não havia primazia da liberdade natural, como agora se estabelece. Havia uma opção discricionária entre libertar o animal ou levá-lo a cativeiro, desrespeitando a dimensão de liberdade ínsita à dignidade animal, reconhecida pela Constituição Federal.

88 Segundo o art. 10 da Lei 5.197/1967, “Os animais de quaisquer espécies, em qualquer fase do seu desenvolvimento e que vivem naturalmente fora do cativeiro, constituindo a fauna silvestre, bem como seus ninhos, abrigos e criadouros naturais são propriedades do Estado, sendo proibida a sua utilização, perseguição, destruição, caça ou apanha". Em complemento, o art. 29 da Lei 9.605/1998 estabelece, como crime, as condutas de "matar, perseguir, caçar, apanhar, utilizar espécimes da fauna silvestre, nativos ou em rota migratória, sem a devida permissão, licença ou autorização da autoridade competente, ou em desacordo com a obtida."

${ }^{89}$ Nesse sentido, Tom Regan afirma que, "Being neither the accountants nor managers of felicity in nature, wildlife managers should be principally concerned with letting animals be, keeping human predators out of their affairs, allowing these 'other nations' to carve out their own destiny" (REGAN, Tom. The case for animal rights. 2. ed. Berkeley: University of California Press, 2004. p. 357): “Não sendo nem contadores nem gerentes de felicidade na natureza, os gestores da vida selvagem devem se preocupar principalmente em deixar os animais em paz, mantendo os predadores humanos fora de seus assuntos, permitindo que essas 'outras nações' estabeleçam seu próprio destino." (tradução nossa).

${ }^{90}$ Cf. STJ, 2a Turma, Resp 1.797.175/SP, Relator Ministro OG FERNANDES, julgado em 21/3/2019, publicado em 28/3/2019.
}

127 |Revista do Programa de Pós-Graduação em Direito da UFBA, e-issn 2358-4777, v. 30, n. 01, p.106 - 136, Jan-Jun 2020 
Entende-se por educação animalista os processos por meio dos quais o indivíduo e a coletividade constroem valores sociais, conhecimentos, habilidades, atitudes e competências voltadas para o respeito à dignidade animal e à abolição das práticas que submetam os animais à crueldade. $^{91}$

Esse princípio é uma ampliação do princípio da educação ambiental, preconizado pelo art. 225, § 1으, VI da Constituição e conceituado no art. 10 da Lei $9.795 / 1999^{92}$, ajustado para promover a conscientização pública sobre a existência da consciência e senciência animal, sobre o sofrimento dos animais envolvidos nas atividades humanas de produção (carne, ovos, couros, peles, etc.), de experimentação científica, de entretenimento, dentre outras, e sobre as alternativas de consumo e de vivência mais éticas, pacíficas e solidárias, dentro de uma perspectiva multiespecífica. Conforme bem lembra Peter Singer, "a ignorância, pois, é a primeira linha de defesa do especista." ${ }^{\prime 3}$

É esse princípio que impõe e legitima o estabelecimento de práticas pedagógicas, campanhas educativas e políticas públicas que induzam e implementem uma ética de respeito à vida e à dignidade animal, de maneira que tem respaldo constitucional o apelo à ética vegana e às dietas vegetarianas, ${ }^{94}$ inclusive destinadas às crianças, em todos os níveis de ensino, ${ }^{95}$ a à comunidade em geral (art. 2ㅇ, X, Lei 6.938/1981).

Da mesma forma, são respaldadas e legitimadas pela Constituição, em virtude dos princípios da dignidade animal e da educação animalista, as campanhas educativas que visam a conscientizar sobre o carnismo, ou seja, "o sistema de crenças que nos condiciona a comer certos animais", ${ }^{96}$ possibilitando escolhas e hábitos de consumo mais conscientes, éticos e direcionados à construção de uma sociedade mais livre, justa e solidária para todos, independentemente da espécie.

O princípio da educação animalista combate o especismo, como prática discriminatória pela espécie, de todo vedada pela Constituição (art. 5ㅇ, XLI), além de atuar contra as formas de estigmatização de certos grupos animais como pragas, destituídos de dignidade própria, o que os torna mais vulneráveis à violência, à crueldade e ao extermínio. ${ }^{97}$

No plano infraconstitucional, o art. 3ㅇ da Lei 13.426/2017, ao disciplinar a política de controle de natalidade de cães e gatos nas cidades, remete ao princípio constitucional da

\footnotetext{
${ }^{91}$ ATAIDE JUNIOR, Vicente de Paula. Introdução ao Direito Animal brasileiro, p. 74.

92 “Art. 1․ Entendem-se por educação ambiental os processos por meio dos quais o indivíduo e a coletividade constroem valores sociais, conhecimentos, habilidades, atitudes e competências voltadas para a conservação do meio ambiente, bem de uso comum do povo, essencial à sadia qualidade de vida e sua sustentabilidade."

${ }^{93}$ Op. cit., p. 247.

${ }^{94} \mathrm{O}$ veganismo, acompanhado da dieta vegetariana estrita, é o padrão de conduta ética que melhor se ajusta ao estado de coisas almejado pelo princípio da dignidade animal e pelo princípio da educação animalista, pois se trata de "una actitud de respeto hacia toda la vida animal no humana sintiente que implica un modo de vida donde se evita voluntariamente su uso, su consumo o la participación en actividades derivadas de su esclavitud, explotación y murte." (ABOGLIO, Ana Maria. Veganismo: práctica de justicia e igualdad. 2. ed. Buenos Aires: Gárgola Ediciones, 2011. p. 74-75): "uma atitude de respeito para com toda a vida animal nãohumana senciente que implica em um modo de vida na qual se evita, voluntariamente, seu uso, seu consumo ou a participação em atividades derivadas de sua escravidão, exploração e morte." (tradução nossa). Nesse sentido: SINGER, Peter, op. cit., p. 201-207; REGAN, Tom, Jaulas vazias: encarando o desafio dos direitos animais, p. 25-42.

${ }^{95}$ Segundo a American Dietetic Association (ADA), conforme posição divulgada em 2009, a dieta vegetariana, nutricionalmente equilibrada, é adequada para todos os estágios da vida humana, inclusive para crianças e para mulheres grávidas ou lactantes. Cf. informações disponíveis em: https://www.vrg.org/nutrition/2009_ADA_position_paper.pdf. Acesso em: 23 abr. 2020.

${ }^{96} \mathrm{JOY}$, Melanie. Por que amamos cachorros, comemos porcos e vestimos vacas: uma introdução ao carnismo: o sistema de crenças que nos faz comer alguns e outros não. Tradução de Mário Molina. São Paulo: Cultrix, 2014. ${ }^{97}$ DONALDSON, Sue; KYMLICKA, Will, op. cit., p. 240.
} 
educação animalista, ao impor a implantação de programa apto a desencadear "campanhas educativas pelos meios de comunicação adequados, que propiciem a assimilação pelo público de noções de ética sobre a posse responsável de animais domésticos."

\section{Princípios compartilhados pelo Direito Animal com outros ramos jurídicos}

Os princípios da dignidade animal, da universalidade, da primazia da liberdade natural e da educação animalista são os princípios estruturantes do Direito Animal brasileiro, decorrentes diretamente do texto constitucional, ainda que possam, em alguns casos, ser mais bem especificados pela legislação infraconstitucional.

Mas, como não poderia deixar de ser, o Direito Animal participa da constelação das disciplinas jurídicas e, por essa razão, compartilha princípios criados a partir de outros ramos do Direito.

No âmbito desta proposta, são catalogados quatro principais princípios compartilhados pelo Direito Animal.

\subsection{Princípio da precaução}

A proteção dos animais contra a crueldade, que vem inscrita no capítulo constitucional dedicado ao meio ambiente, atrai a incidência do denominado princípio da precaução, oriundo do Direito Ambiental. ${ }^{98}$

Segundo o Ministro Luís Roberto Barroso, do Supremo Tribunal Federal, votando na ADIn da vaquejada,

A proteção dos animais contra a crueldade, que vem inscrita no capítulo constitucional dedicado ao meio ambiente, atrai a incidência do denominado princípio da precaução. Tal princípio significa que, na esfera de sua aplicação, mesmo na ausência de certeza científica, isto é, ainda que exista dúvida razoável sobre a ocorrência ou não de um dano, o simples risco já traz como consequência a interdição da conduta em questão. Com mais razão, deve este relevante princípio jurídico e moral incidir nas situações em que a possibilidade real de dano é inequívoca, sendo certo que existem inúmeras situações de dano efetivo." ${ }^{\prime 9}$

O princípio compartilhado da precaução reforça o princípio exclusivo da universalidade: a inexistência de prova científica sobre a senciência de determinada espécie animal não impede a proteção de seus indivíduos pelo Direito Animal.

Pelo mesmo princípio, devem ser interditadas as técnicas ou atividades de controle populacional de animais, sem que reste comprovada, cientificamente, sua eficácia e sua aptidão para garantir a dignidade animal. Por essa razão, a contenção populacional de espécies animais consideradas invasoras exige estudo prévio de impacto ambiental, conforme a Constituição,

\footnotetext{
98 De acordo com o Princípio 15 da Declaração do Rio de Janeiro, da ONU, de 1992, "De modo a proteger o meio ambiente, o princípio da precaução deve ser amplamente observado pelos Estados, de acordo com as suas capacidades. Quando houver ameaça de danos sérios ou irreversíveis, a ausência de absoluta certeza científica não deve ser utilizada como razão para postergar medidas eficazes e economicamente viáveis para prevenir a degradação ambiental." Nesse sentido, ver: BELCHIOR, Germana Parente Neiva, op. cit., p. 141-147; FIGUEIREDO, Guilherme José Purvin de. Curso de direito ambiental. 6. ed. São Paulo: Revista dos Tribunais, 2013. p. 138-143; RODRIGUES, Marcelo Abelha. Elementos de direito ambiental: parte geral. 2. ed. São Paulo: Revista dos Tribunais, 2005. p. 204-208.

${ }^{99}$ STF, Pleno, ADI 4983, Relator Ministro MARCO AURÉLIO, julgado em 06/10/2016, publicado em 27/04/2017.
}

129 |Revista do Programa de Pós-Graduação em Direito da UFBA, e-issn 2358-4777, v. 30, n. 01, p. 106 - 136, Jan-Jun 2020 
dada a potencial submissão dos animais à crueldade, ao sofrimento e à morte, com vulneração dos seus direitos básicos. A liberação de caça amadora, por exemplo, para qualquer pessoa física ou jurídica, como forma de controle populacional de espécie considerada invasora, sem prévio estudo de impacto ambiental, é inconstitucional. ${ }^{100}$

\subsection{Princípio da democracia participativa}

Assim como o Direito Ambiental, o Direito Animal não é produto apenas dos movimentos acadêmicos e científicos. Ele deriva, em grande parte, das reivindicações e dos movimentos sociais organizados para a proteção animal, os quais influenciaram, inclusive, a redação do art. 225 da Constituição Federal.

Seria, hoje, realmente muito difícil imaginar soluções adequadas para a promoção dos direitos fundamentais animais sem uma participação dialogada entre os diversos setores envolvidos: Administração Pública, organizações não-governamentais de defesa e proteção animal (as antigas "sociedades protetoras dos animais"), médicos veterinários, zoólogos, outros cientistas, etc.

O caráter transdisciplinar do Direito Animal ${ }^{101}$ exige uma participação ampliada na produção das suas soluções. O Direito Animal não consegue ser produzido apenas por juristas.

O princípio da democracia participativa, reconhecido pela Constituição, desde o seu art. 1ำ, parágrafo único, até dispositivos como o art. 198, III (participação da comunidade no sistema único de saúde), o art. 204, II (participação popular na formulação das políticas e controles das ações da assistência social), o art. 206, VI (gestão democrática do ensino público), o art. 216-A, § 1으 X (democratização dos processos decisórios com participação e controle social no Sistema Nacional de Cultura) e o art. 227, § 70 (participação popular na formulação das políticas e controles das ações do atendimento dos direitos da criança e do adolescente), também é compartilhado com o Direito Animal, para impor a efetiva participação popular na formulação das políticas públicas e no controle das ações de atendimentos aos direitos fundamentais dos animais não-humanos. ${ }^{102}$

Uma das formas de concretização desse princípio é a instituição, especialmente nos Estados, no Distrito Federal e nos Municípios, dos Conselhos de Direitos Animais, compostos de membros do governo e da sociedade civil, com poderes deliberativos para as políticas públicas de atendimento aos direitos fundamentais animais.

Por meio da atuação, sobretudo, desses Conselhos, o princípio da democracia participativa, no âmbito do Direito Animal, significa promover um estado de coisas em que os interesses animais sejam levados em consideração na formulação das políticas públicas de desenvolvimento. ${ }^{103}$ Isso inclui a elaboração dos planos diretores das cidades (art. 182, § 1, CF e art. 40, § 4으, Lei 10.257/2001) e os zoneamentos ambientais (art. 9o, II, Lei 6.938/1981; art. 4으, III, c, Lei 10.257/2001).

\footnotetext{
${ }^{100}$ A propósito, ver o caso do javali europeu (Sus scrofa) no Brasil e a autorização para caça indiscriminada, sem limite de quantidade e em qualquer época do ano, conforme Instrução Normativa 3/2013, do IBAMA.

101 ATAIDE JUNIOR, Vicente de Paula. Notas sobre o Direito Animal brasileiro. In: Medicina Veterinária do Coletivo: fundamentos e práticos. GARCIA, Rita de Cássia Maria; CALDERÓN, Nestor; BRANDESPIM, Daniel Friguglietti (orgs.). São Paulo: Integrativa Vet, 2018. p. 365.

102 O Município de Belo Horizonte/MG, por meio do Decreto 16.431/2016, ao estabelecer a sua política de defesa e proteção dos animais, incluiu o princípio da participação comunitária ou da cooperação, "o qual pressupõe que o Estado e a sociedade devem andar juntos na defesa dos animais e no desenvolvimento de uma política de proteção adequada" (art. 3, III). Disponível em: http://portal6.pbh.gov.br/dom/iniciaEdicao.do?method=DetalheArtigo\&pk=1169141. Acesso em: 20 abr. 2020. 103 DONALDSON, Sue; KYMLICKA, Will, op. cit., p. 54-55.
} 


\subsection{Princípio do acesso à justiça}

Quem tem direitos, tem o direito de assegurá-los perante o Poder Judiciário. Trata-se da garantia constitucional do acesso à justiça, instituída no art. 5ㅇ, XXXV, da Constituição Federal: "a lei não excluirá da apreciação do Poder Judiciário lesão ou ameaça a direito."

Se os animais são sujeitos de direitos fundamentais, esses direitos podem, sempre, ser defendidos perante a jurisdição e os tribunais. Não há como, na atual realidade democráticoconstitucional brasileira, suprimir a tutela jurisdicional a animais titulares de direitos fundamentais.

O mais importante é perceber a abertura do Direito Processual ao Direito Animal: se os animais têm direitos subjetivos, e a Constituição garante a tutela jurisdicional dos direitos, não há como sonegar capacidade de ser parte aos animais, como indivíduos sencientes e conscientes, dotados de dignidade própria, e legitimidade ativa nas situações concretas.

Evidentemente, os animais não apresentam capacidade processual, ou seja, não podem estar no processo por si próprios. Mas, o direito positivo brasileiro indica como suprir a incapacidade processual: "Os animais serão assistidos em juízo pelos representantes do Ministério Público, seus substitutos legais e pelos membros das sociedades protetoras de animais", conforme art. 2으, § 3ㅇ, do Decreto 24.645/1934, ainda em vigor no Brasil. ${ }^{104}$

\subsection{Princípio da proibição do retrocesso}

Trata-se de conhecido princípio atinente à teoria dos direitos fundamentais, relacionado com o princípio da segurança jurídica e com seus respectivos desdobramentos, bem como conectado com os limites materiais de reforma constitucional - as cláusulas pétreas, conforme art. 60, § 4으, da Constituição. ${ }^{105}$

Os avanços constitucionais e legislativos em termos de reconhecimento de direitos fundamentais animais - como o art. 5o do Código de Direito e Bem-Estar Animal do Estado da Paraíba - restam imunizados a alterações que possam suprimir-lhes ou reduzir-lhes o alcance.

Com base nesse princípio é que se pode sustentar, por exemplo, a inconstitucionalidade da Emenda Constitucional 96/2017, a qual introduziu o § 70 ao art. 225 da Constituição para dizer que

não se consideram cruéis as práticas desportivas que utilizem animais, desde que sejam manifestações culturais, conforme o $\S 10$ do art. 215 desta Constituição Federal, registradas como bem de natureza imaterial integrante do patrimônio cultural brasileiro, devendo ser regulamentadas por lei específica que assegure o bem-estar dos animais envolvidos.

Da mesma forma, a Lei Estadual 17.526, de 28 de maio de 2018, de Santa Catarina, que alterou o art. 34-A do Código Estadual de Proteção dos Animais - Lei Estadual 12.854/03 - para excluir os cavalos da qualificação de sujeitos de direitos. ${ }^{106}$

\footnotetext{
${ }^{104}$ BENJAMIN, Antônio Herman de Vasconcellos e. A natureza no direito brasileiro: coisa, sujeito ou nada disso. Caderno Jurídico da Escola Superior do Ministério Público do Estado de São Paulo, São Paulo, ano 1, v. 1, n. 02 , p. 149-169, jul. 2001. p. 155.

${ }^{105}$ SARLET, Ingo Wolfgang; FENSTERSEIFER, Tiago, op. cit., p. 301-302.

${ }^{106} \mathrm{O}$ art. 34-A desse Código estadual, bastante inovador, estabeleceu que, "Para os fins desta Lei, cães, gatos e cavalos ficam reconhecidos como seres sencientes, sujeitos de direito, que sentem dor e angústia, o que constitui o reconhecimento da sua especificidade e das suas características em face de outros seres vivos" (art. 34-A, acrescido pela Lei Estadual 17.485/2018). A Lei 17.526/2018 suprimiu os cavalos desse dispositivo, violando o princípio da vedação ao retrocesso em matéria de direitos fundamentais animais.
}

131 Revista do Programa de Pós-Graduação em Direito da UFBA, e-issn 2358-4777, v. 30, n. 01, p.106 - 136, Jan-Jun 2020 
O princípio da proibição do retrocesso, em matéria de direitos fundamentais animais, reforça a impossibilidade de se liberar práticas como a farra do boi, ${ }^{107}$ as rinhas de galo ${ }^{108}$ e a vaquejada $^{109}$ já consideradas inconstitucionais pelo Supremo Tribunal Federal, por serem intrinsecamente cruéis e discreparem da regra da proibição da crueldade. A interdição judicial dessas atividades foi um avanço civilizatório, em relação ao qual não se pode retroceder. ${ }^{110}$

\section{Conclusões propositivas}

Este ensaio é uma introdução à principiologia do Direito Animal, contendo uma proposta de sistematização de princípios exclusivos e não-exclusivos (compartilhados com outros ramos do Direito), considerando o objeto da disciplina, delineado em seu conceito.

Essa proposta leva em conta os seguintes pressupostos da Teoria dos Princípios de Humberto Ávila:

(1) regras e princípios são normas jurídicas de primeiro grau, porque são elas objeto da aplicação; enquanto as regras desde logo apontam a conduta a ser adotada, os princípios estabelecem um estado de coisas a ser promovido, a partir do qual se podem definir as condutas necessárias para os promover; os princípios, portanto, não são meras exortações valorativas, mas normas jurídicas finalísticas, que sempre exigem condutas aptas à realização do fim almejado;

(2) no estabelecimento de princípios, o intérprete deve apontar o estado de coisas a ser promovido e as condutas necessárias para alcançar esse ideal, ou seja, não basta indicar o valor subjacente ao princípio, sem descrever o seu conteúdo;

(3) de um mesmo dispositivo ou enunciado normativo é possível extrair-se uma ou mais regras e um ou mais princípios.

Assim considerado, do dispositivo inscrito no art. 225, § 1으, VII, in fine, da Constituição Federal de 1988, pode-se extrair, desde logo, a regra da proibição das práticas cruéis contra animais, dada à descrição direta e imediata da conduta proibida.

No entanto, desse mesmo dispositivo podem ser extraídos os princípios específicos do Direito Animal:

(1) Princípio da dignidade animal: o dispositivo constitucional, ao proibir a crueldade contra animais, reconhece, implicitamente, a senciência animal; ao considerar que os animais são importantes como indivíduos sencientes, reconhece-lhes, implicitamente, uma dignidade própria, de onde exsurge o princípio. O estado de coisas a ser promovido é o redimensionamento do status jurídico dos animais não-humanos, de coisas para sujeitos, impondo ao Poder Público e à coletividade comportamentos que respeitem esse novo status, seja agindo para proteger, seja abstendo-se de maltratar ou praticar, contra eles, atos de crueldade ou que se mostrem incompatíveis com a sua dignidade peculiar;

(2) Princípio da universalidade: do mesmo dispositivo constitucional percebe-se a ausência de distinção entre espécies animais dignas de proteção contra a crueldade, o que permite extrair o aludido princípio. $O$ estado de coisas a ser promovido é a universalidade protetiva, proibindose as condutas, inclusive legislativas e administrativas, que manifestem preconceito ou

\footnotetext{
107 STF, 2a Turma, Relator Ministro FRANCISCO REZEK, Acórdão lavrado pelo Ministro MARCO AURÉLIO, julgado em 03/6/1997, publicado em 13/3/1998.

108 STF, Pleno, ADIn 2514-7/SC, Relator Ministro EROS GRAU, julgado em 29/6/2005, publicado em 09/12/2005; STF, Pleno, ADIn 3776-5/RN, Relator Ministro CÉZAR PELUSO, julgado em 14/6/2007, publicado em 29/6/2007; STF, Pleno, ADIn 1856/RJ, Relator Ministro CELSO DE MELLO, julgado em 26/5/2011, publicado em 14/10/2011. ${ }^{109}$ STF, Pleno, ADI 4983, Relator Ministro MARCO AURÉLIO, julgado em 06/10/2016, publicado em 27/04/2017. 110 Sobre o princípio da vedação do retrocesso, em matéria ambiental, no Supremo Tribunal Federal, ver decisão do Ministro Celso de Mello, disponível em: http://www.stf.jus.br/arquivo/cms/noticiaNoticiaStf/anexo/ADI6218cautelar.pdf. Acesso em: 29 abr. 2020.
}

132 |Revista do Programa de Pós-Graduação em Direito da UFBA, e-issn 2358-4777, v. 30, n. 01, p.106 -136, Jan-Jun 2020 
discriminação pela espécie, notadamente constatadas pelo desprezo à dignidade de animais de uma determinada espécie ou grupo animal, aos quais se sonegam direitos fundamentais;

(3) Princípio da primazia da liberdade natural: esse princípio decorre da dignidade animal, de sede constitucional, na sua dimensão de liberdade, porém, é mais bem especificado a partir do dispositivo legal contido no art. $25, \S 1$ o, da Lei 9.605/1998, o qual estabelece que, prioritariamente, os animais devem ser restituídos ao seu habitat. 0 estado de coisas a ser promovido é a manutenção dos animais silvestres no seu habitat, no qual podem manifestar o seu comportamento natural. Com isso, impõe-se que os estabelecimentos que recebam animais silvestres adotem as condutas necessárias para os reintegrar à natureza, proibindo-se as práticas tendentes à sua manutenção injustificada em cativeiro;

(4) Princípio da educação animalista: esse princípio é extraído do dispositivo constitucional que impõe ao Poder Público o dever de promover a educação ambiental em todos os níveis de ensino e a conscientização pública para a preservação do meio ambiente (art. 225, § 10, VI). Como também é dever do Poder Público proteger a dignidade animal (art. 225, § 10, VII), nesse dever se inclui a educação animalista, pela qual se opera a conscientização pública para o reconhecimento da dignidade animal, dos direitos fundamentais animais e da proibição das práticas cruéis. $O$ estado de coisas a ser promovido é a sociedade brasileira consciente que animais são seres sencientes e conscientes, que desfrutam de experiências subjetivas, dotados de dignidade própria e merecedores de respeito, não por compaixão, mas por serem titulares de direitos fundamentais próprios. O princípio, consequentemente, impõe condutas administrativas para o estabelecimento de programas e de políticas públicas de educação animalista.

Os princípios não-exclusivos ou compartilhados do Direito Animal têm sua origem, derivação normativa e justificação bem estabelecidas em outros campos do saber jurídico. No entanto, vale a pena apontar o estado de coisas que tais princípios promovem em relação ao Direito Animal:

(1) Princípio da precaução: promove a universalidade da proteção aos animais, ao impedir a sonegação de direitos fundamentais pela inexistência de prova científica sobre a consciência ou a senciência de determinada espécie animal;

(2) Princípio da democracia participativa: promove a efetiva participação popular na formulação das políticas públicas e no controle das ações de atendimentos aos direitos fundamentais dos animais não-humanos;

(3) Princípio do acesso à justiça: promove a tutela jurisdicional dos direitos fundamentais animais, possibilitando que os animais sejam sujeitos do processo, assistidos em juízo por quem a lei indicar;

(4) Princípio da proibição do retrocesso: promove a manutenção das conquistas legislativas e jurisprudenciais em termos de direitos fundamentais animais, impedindo que novas leis ou novas decisões possam significar a abolição, a redução ou a ineficácia desses direitos.

Como se pode intuir, o acréscimo dos princípios ao lado da regra da proibição da crueldade tende a ampliar, consideravelmente, o alcance normativo do Direito Animal, fortalecendo-o, sem contribuir para a crise panprincipiológica (princípios despidos de normatividade) ${ }^{111}$, dado que tais princípios não são invenções filosóficas, mas elementos colhidos do próprio ordenamento jurídico brasileiro.

\section{Referências}

ABOGLIO, Ana Maria. Veganismo: práctica de justicia e igualdad. 2. ed. Buenos Aires: Gárgola Ediciones, 2011.

${ }^{111}$ STRECK, Lenio Luiz, op. cit., p. 524 et seq.

133 |Revista do Programa de Pós-Graduação em Direito da UFBA, e-issn 2358-4777, v. 30, n. 01, p. 106 - 136, Jan-Jun 2020 
ACKEL FILHO, Diomar. Direito dos animais. São Paulo: Themis, 2001.

ALEXY, Robert. Teoria dos direitos fundamentais. Tradução de Virgílio Afonso da Silva. 2. ed. São Paulo: Malheiros, 2017.

ARAÚJO, Fernando. A hora dos direitos dos animais. Portugal: Almedina, 2003.

ATAIDE JUNIOR, Vicente de Paula. Código de bem-estar animal da Paraíba deve servir de modelo para o Brasil. Consultor Jurídico (CONJUR). Disponível em: https://www.conjur.com.br/2018-dez23/vicente-paula-codigo-paraiba-modelo-direito-animal. Acesso em: 24 dez. 2018.

(coord.). Comentários ao Código de Direito e Bem-Estar Animal do Estado da Paraíba: a positivação dos direitos fundamentais animais. Curitiba: Juruá, 2019.

. Introdução ao Direito Animal brasileiro. Revista Brasileira de Direito Anima, Salvador, v. 13,

n. 3, p. 48-76, set./dez. 2018.

Notas sobre o Direito Animal brasileiro. In: Medicina Veterinária do Coletivo: fundamentos

e práticos. GARCIA, Rita de Cássia Maria; CALDERÓN, Nestor; BRANDESPIM, Daniel Friguglietti (orgs.). São Paulo: Integrativa Vet, 2018. p. 365-383.

ÁVILA, Humberto Bergmann. Teoria dos princípios: da definição à aplicação dos princípios jurídicos. 18. ed. São Paulo: Malheiros, 2018.

BELCHIOR, Germana Parente Neiva. Fundamentos epistemológicos do Direito Ambiental. Rio de Janeiro: Lúmen Júris, 2017.

BENJAMIN, Antônio Herman de Vasconcellos e. A natureza no direito brasileiro: coisa, sujeito ou nada disso. Caderno Jurídico da Escola Superior do Ministério Público do Estado de São Paulo, São Paulo, ano 1, v. 1, n. 02, p. 149-169, jul. 2001.

BONAVIDES, Paulo. Curso de direito constitucional. 27. ed. São Paulo: Malheiros, 2012.

BORGES, Daniel Moura. A Declaração Universal dos Direitos dos Animais como norma jurídica: sua aplicação enquanto soft law e hard law. 120 f. Dissertação (Mestrado) - Faculdade de Direito - Universidade Federal da Bahia, Salvador, 2015.

CORDOVIL, Anaiva Oberst. Direito animal. Rio de Janeiro: Lumen luris, 2012.

DESCARTES, René. Discurso do método. Porto Alegre: L\&PM, 2009.

DIAS, Edna Cardozo. A tutela jurídica dos animais. Belo Horizonte: Mandamentos, 2000.

DONALDSON, Sue; KYMLICKA, Will. Zoopolis: a political theory of animal rights. Oxford: Oxford University Press, 2011.

DUNAYER, Joan. Animal equality: language and liberation. Derwood: Ryce Publishing, 2001.

DWORKIN, Ronald. Levando os direitos a sério. Tradução Nelson Boeira. 3. ed. São Paulo: WMF Martins Fontes, 2010.

FACHIN, Zulmar; SILVA, Deise Marcelino da. Acesso à água potável: direito fundamental de sexta dimensão. Campinas: Millennium Editora, 2010.

FELIPE, Sonia Teresinha. Por uma questão de princípios: alcance e limites da ética de Peter Singer em defesa dos animais. Florianópolis: Fundação Boiteux, 2003.

FERRAZ JUNIOR, Tércio Sampaio. Introdução ao estudo do direito: técnica, decisão, dominação.

3. ed. São Paulo: Atlas, 2001.

FIGUEIREDO, Guilherme José Purvin de. Curso de direito ambiental. 6. ed. São Paulo: Revista dos Tribunais, 2013.

FRANCIONE, Gary Lawrence. Animals, property and the law. Philadelphia: Temple University Press, 1995.

Introdução aos direitos animais: seu filho ou o cachorro? Tradução de Regina Rheda. Campinas: Editora da Unicamp, 2013.

GORDILHO, Heron José de Santana. Abolicionismo animal. Salvador: Evolução, 2008.

GRAU, Eros. Por que tenho medo dos juízes: a interpretação/aplicação do direito e os princípios.

9. ed. São Paulo: Malheiros, 2018. 
HÄBERLE, Peter. A dignidade humana como fundamento da comunidade estatal. In: SARLET, Ingo Wolfgang (org.). Dimensões da dignidade: ensaios de filosofia do direito e direito constitucional. 2. ed. Porto Alegre: Livraria do Advogado Editora, 2013.

JOY, Melanie. Por que amamos cachorros, comemos porcos e vestimos vacas: uma introdução ao carnismo: o sistema de crenças que nos faz comer alguns e outros não. Tradução de Mário Molina. São Paulo: Cultrix, 2014.

KANT, Immanuel. Fundamentação da metafísica dos costumes. Tradução de Inês A. Lohbauer. São Paulo: Martin Claret, 2018.

LEVAI, Laerte Fernando. Direito dos animais. 2. ed. Campos do Jordão: Mantiqueira, 2004.

LÔBO, Paulo. Direito civil. 7. ed. São Paulo: Saraiva Educação, 2018. v. 4.

LOURENÇO, Daniel Braga. Direito dos animais: fundamentação e novas perspectivas. Porto Alegre: Sérgio Antonio Fabris Editor, 2008.

; OLIVEIRA, Fábio Corrêa Souza de. Vedação da crueldade contra animais: regra ou princípio constitucional? Revista de Direito Fundamentais \& Democracia, v. 24, n. 2, p. 222-252, maio/ago. 2019. Disponível

em:

https://revistaeletronicardfd.unibrasil.com.br/index.php/rdfd/article/view/1294/590. Acesso em: 2 abr. 2020.

MACEDO, José Arthur Castillo de. Encruzilhadas do federalismo: transfederalismo, cooperação, constitucionalismo e democracia. Curitiba, 2018, 223 p. Tese (Doutorado em Direito) - Programa de Pós-Graduação em Direito da Universidade Federal do Paraná. Disponível em: https://acervodigital.ufpr.br/bitstream/handle/1884/63219/R\%20-\%20T\%20-

\%20JOSE\%20ARTHUR\%20CASTILLO\%20DE\%20MACEDO.pdf?sequence=1\&isAllowed=y. Acesso em: 2 abr. 2020.

MAROTTA, Clarice Gomes. Princípio da dignidade dos animais: reconhecimento jurídico e aplicação. Belo Horizonte: Editora D’Plácido, 2019.

MEDEIROS, Fernanda Luiza Fontoura de. Direito dos animais. Porto Alegre: Livraria do Advogado, 2013.

MIGLIORE, Alfredo Domingues Barbosa. Personalidade jurídica dos grandes primatas. Belo Horizonte: Del Rey, 2012.

MOLINARO, Carlos Alberto; MEDEIROS, Fernanda Luiz Fontoura de; SARLET, Ingo Wolfgang, FENSTERSEIFER, Tiago (coords). A dignidade da vida e os direitos fundamentais para além dos humanos: uma discussão necessária. Belo Horizonte: Editora Fórum, 2008.

MORAES, Alexandre Rocha Almeida de. A teoria dos mandados de criminalização e o combate efetivo à corrupção. Revista Jurídica ESMP-SP, v. 5, p. 43-68, 2014. Disponível em: http://www.esmp.sp.gov.br/revista_esmp/index.php/RJESMPSP/article/download/170/65.

Acesso em: 20 abr. 2020.

NEVES, Marcelo. Transconstitucionalismo. São Paulo: WMF Martins Fontes, 2009.

ORWELL, George. Revolução dos bichos. Tradução de Heitor Aquino Ferreira. São Paulo: Globo, 2003.

REGAN, Tom. The case for animal rights. 2. ed. Berkeley: University of California Press, 2004.

Jaulas vazias: encarando o desafio dos direitos animais. Tradução de Regina Rheda. Revisão técnica de Sônia T. Felipe e Rita Paixão. Porto Alegre: Lugano, 2006.

RODRIGUES, Marcelo Abelha. Elementos de direito ambiental: parte geral. 2. ed. São Paulo: Revista dos Tribunais, 2005.

SARLET, Ingo Wolfgang. A eficácia dos direitos fundamentais: uma teoria geral dos direitos fundamentais na perspectiva constitucional. 12. ed. Porto Alegre: Livraria do Advogado, 2015.

; FENSTERSEIFER, Tiago. Direito constitucional ambiental: Constituição, direitos fundamentais e proteção do ambiente. 5. ed. São Paulo: RT, 2017. 
SCHÄFER, Jairo. Classificação dos direitos fundamentais: do sistema geracional ao sistema unitário: uma proposta de compreensão. 3. ed. Porto Alegre: Livraria do Advogado, 2018.

SILVA, Tagore Trajano de Almeida. Direito animal e ensino jurídico: formação e autonomia de um saber pós-humanista. Salvador: Evolução, 2014.

SINGER, Peter. Libertação animal. Porto Alegre, São Paulo: Lugano, 2004.

STRECK, Lenio Luiz. Verdade e consenso: constituição, hermenêutica e teorias discursivas. 5. ed. São Paulo: Saraiva, 2014.

TRINDADE, Gabriel Garmendia da. Especismo, linguagem e a percepção humana dos demais animais. In: SCHEFFER, Gisele Kronhardt (coord.). Direito Animal e ciências criminais. Porto Alegre: Canal Ciências Criminais, 2018. p. 59-66.

WISE, Steven M. Animal rights, one step at a time. In: SUNSTEIN, Cass R.; NUSSBAUM, Martha Craven (org.). Animal rights: current debates and new directions. Oxford University Press, 2004. p. 19-50. 